\title{
Jobbágyból nemes - a Kutacs család történetén keresztül
}

A nemesség történetének vizsgálata és kutatása régi időkre nyúlik vissza. E rend széles talapzatát testesítették meg a címereslevéllel (litterae armales) rendelkező famíliák. ${ }^{1}$ A Magyar Királyság területéről nagyjából százezer nemeslevelet ismerünk, többségüket már feldolgozták és publikálták. ${ }^{2}$ E nemesi rétegről ${ }^{3}$ valamint az oklevelek társadalom- és müvészettörténeti értékeinek fontosságáról a közelmúltban is jelentek meg új kutatási eredmények. ${ }^{4} \mathrm{Az}$ eltelt évszázadok számtalan armálist ítéltek pusztulásra, a fennmaradtak döntő része pedig levéltárakban pihen. Ezek mellett, időről-időre kerülnek elő olyan nemesi levelek, melyek családon belül apáról-fiúra öröklődtek, és ma is magántulajdonban vannak, „ereklyeként” őrizve.

A címben szereplő Kutacs család ősei és azok leszármazottai már sok évszázada Bolyok $^{5}$ községben éltek. A família jobbágyi eredetü, velük kapcsolatos okleveles emlékekről nincs tudomásom. A Magyar Kamara irattárában a 16. századtól kezdődően fennmaradt dézsmajegyzékek azok a források, melyek elsőként - név szerint - örökítették meg a településen élő gazdálkodókat. ${ }^{6}$ 1548-ban a gabonatizedlajstrom 18, helybeli jobbágy nevét sorolta fel, utolsó előttiként jegyzékbe véve

${ }^{1}$ Vö. ECKHARDT SÁNDOR: Úr és paraszt a magyar élet egységében. Bp., 1941.

${ }^{2}$ NyUlásziné Straub Éva: Öt évszázad címerei, a Magyar Országos Levéltár címereslevelein. Bp., 1987. 14.

${ }^{3}$ SZÁLKAI TAMÁs: Armálisok és armalisták a kora újkori Biharban : a Hajdú-Bihar Megyei Levéltár egyéni címeres nemeslevelei (1535-1811) és nemesi iratai alapján (egyetemi doktori (PhD) értekezés). Debrecen, 2010. Uő.: Címeres nemeslevelek a Magyar Nemzeti Levéltár Hajdú-Bihar Megyei Levéltárában. Debrecen, 2016.

${ }^{4}$ SZÁLKAI TAMÁs: Armales Transylvanorum: válogatás az erdélyi fejedelmek címeradományaiból. Máriabesnyő-Gödöllő, 2009.; SzÁLKAI TAMÁs: Nagytúri Thury Ferenc armálisa a Hajdú-Bihar Megyei Levéltár diplomagyüjteményéből: forrásközlés. Levéltári Szemle. 2006. (56. évf.) 4. sz. 3-11.

${ }^{5}$ Bolyok és Sajóvárkony nagyközségek 1940. január 1-jén a Magyar Királyi Belügyminisztérium 6663/1939. II. (V. III.) b számú utasítása alapján egyesültek Ózd nagyközséggel, amelyet a belügyminiszter az 1948. október 13-án kiadott 181518/1948. (111. 03.) BM M. számú rendeletével 1949. január 1-jétől városi rangra emelt.

${ }^{6}$ A dézsmajegyzékek mai lelőhelye a Magyar Nemzeti Levéltár Országos Levéltárának Mikrofilmtára, E szekció, Regesta decimarum (E 159). A tizedösszeírások mikrofilm másolatban érhetők el a MNL Borsod-Abaúj-Zemplén Megyei Levéltára XV. 32. jelzet alatt. Kutatásaimat ezek felhasználásával végeztem. 
Kutacs Pált (Palus Kwtach), ${ }^{7}$ aki zsellérként 6 dénár kereszténypénzt (Pecunia Christianitatis) fizetett. ${ }^{8}$

1552-ben a török sereg sikertelenül ostromolta - az ugyancsak Bolyokról származó Bolyki Tamás vitézsége okán is - Eger várát. 1554. szeptember 4-én azonban elfoglalták Füleket, és az új bég számos borsodi falut égettetett fel. ${ }^{9}$ Erre a sorsra jutott 1556-ban Bolyok is. ${ }^{10}$ Borsod vármegye ettől kezdve egészen 1596-ig kettős adózású területnek számított. 1593. november 11-én Tauffenbach Kristóf Füleknél megverte a törököket, 17-én pedig Pálffy Miklós a várat is visszavette, így a megye észak felől mentesült. ${ }^{11}$ Viszont 1596-ban elesett Eger erődje, és az azt követő mezőkeresztesi csatában ismét keresztény vereség következett, mellyel újabb száz esztendőre állandósult a hódoltság a vidéken. ${ }^{12}$

Az oszmánok a katonai hódítások mellett nagy hangsúlyt fektettek az adózó népesség nyilvántartására, teherbíró képességének precíz felmérésére is. Hivatali apparátusuk időről-időre elkészítette az adóösszeírásokat (defterek). Ezekben név szerint feljegyezték az adófizető családfőket, valamint azok 15 éven felüli fiait, testvéreit. ${ }^{13}$ 1570-ből ismeretes a Hatvani szandzsák adóösszeírása, melyben a Putnoki náhijéhoz tartozó Bolyok ${ }^{14}$ faluban Kutacs Ferenccel, Kutacs Imrével és ennek fiával Pállal találkozunk. ${ }^{15}$

1548-at követően csak 1576-tól állnak rendelkezésünkre újabb tizedjegyzékek, ettől kezdve azonban több évből is. ${ }^{16} \mathrm{E}$ században 12 alkalommal kerül említésre bennük a família. (1. kép.)

\footnotetext{
${ }^{7}$ NAGY KÁROLY: Régi históriák : Ózd és környéke múltjának irott forrásai : Helytörténeti olvasókönyv. Ózd, 1984. 31-32.

${ }^{8}$ MNL BAZML XV. 32. Dézsmajegyzékek. 358. tek.

${ }^{9}$ Vö. MARKUS KÖHBACH: Die Eroberung von Fülek durch die Osmanen 1554 : Eine historisch-quellenkritische Studie zur osmanischen Expansion im östlichen Mittteleuropa. Wien; Köln; Weimar, 1994.

${ }^{10}$ BorovsZKY SAMU: Borsod vármegye története a legrégibb időktöl a jelenkorig. Bp., 1909. 85-86.

${ }^{11}$ KLEIN GÁSPÁR: Borsod vármegye és népességének története. Borsod vármegye : vármegyei szociográfiák V. Szerk.: CSIKVÁRI ANTAL. Budapest, 1939. 35.

${ }^{12}$ BodnÁRnÉ Moldován Éva: Borsod-Abaúj-Zemplén megye története. Borsod-AbaújZemplén megye hon- és népismerete. Szerk.: SOMORJAI LEHEL. Miskolc, 2004. 53.

${ }^{13}$ VASS ELŐD: Borsod megye török adóztatása az egri vár eleste elött, 1544-1596. Borsodi levéltári évkönyv IV. Szerk.: RoMÁN JÁNOS. Miskolc, 1981. 50.

${ }^{14}$ Bolog alakban.

${ }^{15}$ BAYERLE GUSZTÁv: A hatvani szandzsák adóösszeírása 1570-böl = Defter Mufassal-I Liva Hatvan (Basbakanlik Arsivi, TD 550). Hatvan, 1998. 246.

${ }^{16}$ MNL BAZML XV. 32. Dézsmajegyzékek. 1576. év 360. tek. ; 1577. év 361. tek. ; 1578. év 362. tek. ; 1579. év 362. tek. ; 1580. év 363. tek. ; 1581. év 364. tek. ; 1582. év 365. tek. ; 1583. év 365. tek. ; 1594. év 368. tek. ; 1597. év 369. tek. ; 1598. év 369. tek. ; 1599. és 1600. év 370. tek. 1601-1604. év 371. tek. ; 1605-1606. év 372. tek. ; 1607-1609. év 373. tek. ; 1614. év 374. tek. ; 1616. év 375. tek. ; 1619-1620. év 376. tek. ; 1621-1622. év 377. tek. ; 1623. év 378. tek. ; 1624. év 378. tek. ; 1626. év 379. tek. ; 1627. év 380. tek. ; 1647. év 381. tek. ; 1660. év 382. tek. ; 1662. év 382. tek. ; 1663. év 382. tek. ; 1664. év 382. tek. ; 1672. év 382. tek. ; 1673. év 382. tek. ; 1674-1686. év 383. tek. ; 1688-1693. év 384. tek. ; 1694-1716. év 385. tek.
} 


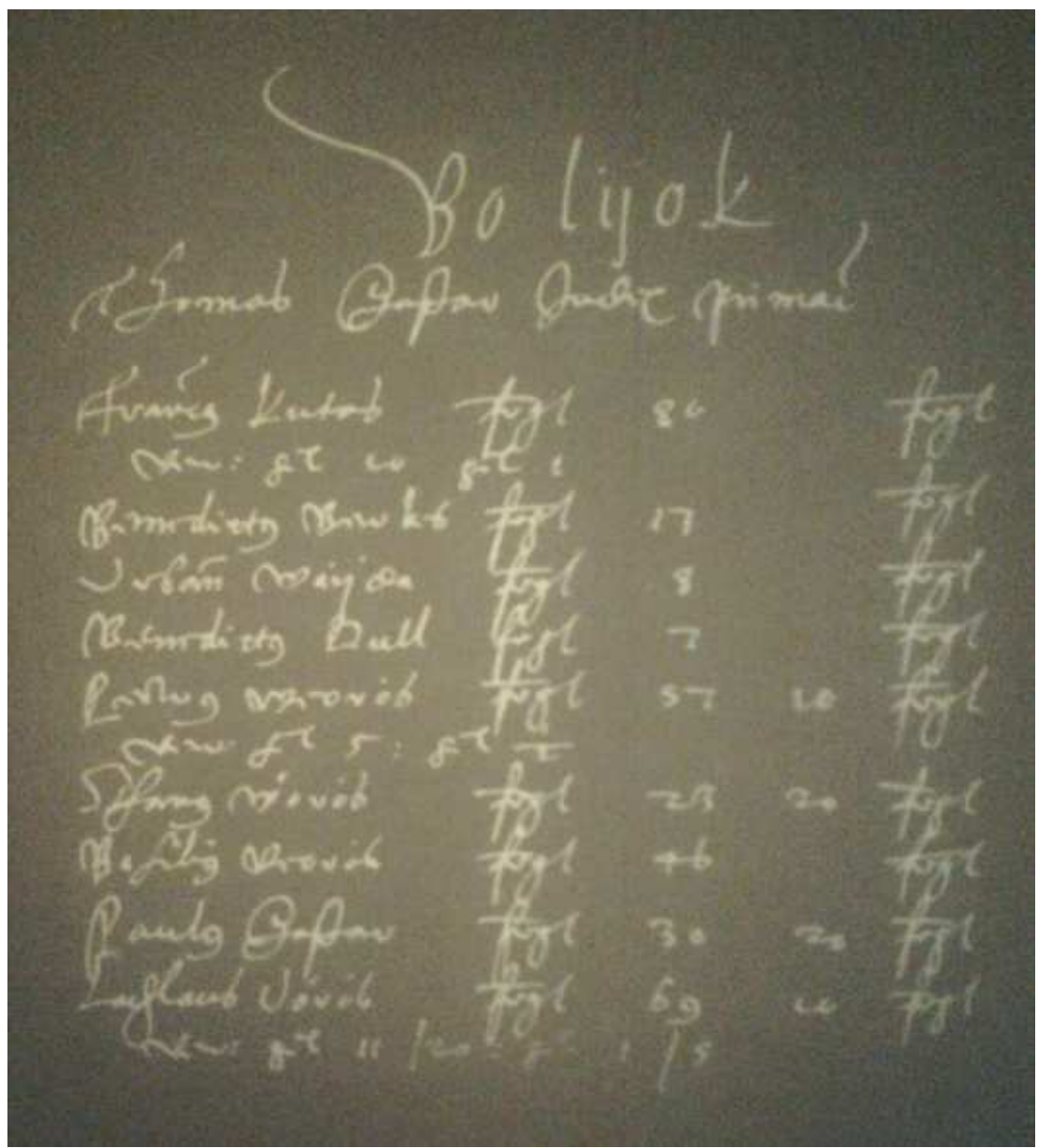

1. kép. Bolyok 1583-as gabonadézsma-jegyzéke (részlet).

A dézsmajegyzékek nemcsak az adófizetők nevét, hanem termésmennyiségeiket is megörökítették, melyből az egyes családok gazdasági ereje is megállapítható. ${ }^{17} \mathrm{~A}$ 16. század második felében keletkezett lajstromok alapján az alábbi táblázatban összegeztem a família egyes tagjainak adótételeit:

\footnotetext{
${ }^{17}$ A tizedjegyzékekben általában az egyházi tized címén kivett gabona mennyiségét tüntették fel. Rendszerint elötte már a kilenced járandóságát is teljesítette a jobbágy. Ebből visszafelé számolva megállapítható a gazdálkodó termésének teljes mennyisége. A számítás módját ILA BÁLINT közli: „Ha a tizedjegyzékben csak a kivett tized mennyiségét jegyezték fel és ebböl kell a teljes termést kiszámítani, akkor a tizedet 11,25-tel kell szorozni. ... a 90 kepéböl 10 kepe kilenced után kivett 8 kepe tized 11,25-szörös szorzata adja ki a 90 kepe teljes termést." Lásd: IlA BÁLINT: A dézsmajegyzékek mint a történeti statisztika forrásai. A történeti statisztika forrásai. Szerk.: KovACSICS JózSEF. Bp., 1957. 102.
} 


\begin{tabular}{|c|c|c|c|c|c|c|}
\hline $\begin{array}{l}\text { Sor- } \\
\text { szám }\end{array}$ & Adóév & Adózó neve & $\begin{array}{l}\text { Öszi gabona } \\
\text { termés }\end{array}$ & $\begin{array}{l}\text { Tavaszi gabona } \\
\text { termés }\end{array}$ & $\begin{array}{l}\text { Méhkas } \\
(\mathrm{db})\end{array}$ & CHD18 \\
\hline 1. & 1548 & Kutacs Pál & - & - & - & 6 \\
\hline 2. & 157019 & $\begin{array}{l}\text { Kutacs Ferenc, } \\
\text { Kutacs Imre és } \\
\text { fia Kutacs Pál }\end{array}$ & \multicolumn{4}{|c|}{$\begin{array}{l}\text { A török összeírás a falu különböző jövedelemforrását } \\
\text { egy-egy tételben összegzi, így az egyes termelők javai } \\
\text { nem kiszámíthatók. }\end{array}$} \\
\hline 3. & 1576 & Kutacs Ferenc & $\begin{array}{l}73,125 \text { gl20 } \\
(43,875 \text { q21) }\end{array}$ & $\begin{array}{l}22,5 \mathrm{gl} \\
(13,5 \mathrm{q})\end{array}$ & 3 & - \\
\hline 4. & 1577 & Kutacs Ferenc & $\begin{array}{l}139,5 \mathrm{gl} \\
(83,7 \mathrm{q})\end{array}$ & $\begin{array}{l}16,875 \mathrm{gl} \\
(10,125 \mathrm{q})\end{array}$ & - & - \\
\hline 5. & 1578 & Kutacs Pál & $\begin{array}{l}20,812 \mathrm{gl} \\
(12,487 \mathrm{q})\end{array}$ & - & - & - \\
\hline \multirow[b]{2}{*}{6.} & \multirow[t]{2}{*}{1579} & Kutacs Ferenc & $\begin{array}{l}22,5 \mathrm{gl} \\
(13,5 \mathrm{q})\end{array}$ & - & - & - \\
\hline & & Kutacs Pál & $\begin{array}{l}19,125 \mathrm{gl} \\
(11,475 \mathrm{q})\end{array}$ & - & - & - \\
\hline \multirow[t]{2}{*}{7.} & \multirow[t]{2}{*}{1580} & Kutacs Ferenc & $\begin{array}{l}118,125 \mathrm{gl} \\
(70,875 \mathrm{q})\end{array}$ & - & - & - \\
\hline & & Kutacs Pál & $\begin{array}{l}25,875 \mathrm{gl} \\
(15,525 \mathrm{q})\end{array}$ & - & - & - \\
\hline \multirow[t]{2}{*}{8.} & \multirow[t]{2}{*}{1581} & Kutacs Ferenc & $\begin{array}{l}39,375 \mathrm{gl} \\
(23,625 \mathrm{q})\end{array}$ & $\begin{array}{l}6,75 \mathrm{gl} \text { és } \\
(4,05 \mathrm{q})\end{array}$ & - & - \\
\hline & & Kutacs Pál & $\begin{array}{l}7,875 \mathrm{gl} \\
(4,725 \mathrm{q}) \\
\end{array}$ & $\begin{array}{l}1,8 \mathrm{gl} \\
(1,08 \mathrm{q})\end{array}$ & - & - \\
\hline \multirow[t]{2}{*}{9.} & \multirow[t]{2}{*}{1582} & Kutacs Ferenc & $\begin{array}{l}22,5 \mathrm{gl} \\
(13,5 \mathrm{q})\end{array}$ & $\begin{array}{l}7,875 \mathrm{gl} \\
(4,725 \mathrm{q})\end{array}$ & - & - \\
\hline & & Kutacs Pál & $\begin{array}{l}15 \mathrm{gl} \\
(9 \mathrm{q})\end{array}$ & - & - & - \\
\hline \multirow[t]{3}{*}{10.} & \multirow[t]{3}{*}{1583} & Kutacs Ferenc & $\begin{array}{l}90 \mathrm{gl} \\
(54 \mathrm{q})\end{array}$ & $\begin{array}{l}11,25 \mathrm{gl} \\
(6,75 \mathrm{q})\end{array}$ & 2 & - \\
\hline & & Kutacs Pál & $\begin{array}{l}30 \mathrm{gl} \\
(18 \mathrm{q})\end{array}$ & - & 2 & - \\
\hline & & Kutacs Imre & - & - & - & 6 \\
\hline 11. & 1594 & $\begin{array}{l}\text { Kutacs Imre } \\
\text { (bíró) }\end{array}$ & & & & \\
\hline 12. & 1598 & $\begin{array}{l}\text { Kutacs Imre } \\
\text { (bíró) }\end{array}$ & & & & \\
\hline 13. & 1599 & $\begin{array}{l}\text { Kutacs Imre } \\
\text { (bíró) }\end{array}$ & & & & \\
\hline 14. & 1600 & $\begin{array}{l}\text { Kutacs } \\
\text { Demeter (bíró) }\end{array}$ & & & & \\
\hline
\end{tabular}

\footnotetext{
${ }^{18}$ A kereszténypénzt fizetők rövidítése (CHristianitatis Denarii).

${ }^{19}$ BAYERLE: i. m., 246.

${ }^{20}$ A gelima rövidítése, amely elszámolási egység volt. Vidékünkön a 16. században 30 kévét foglalt magába.

${ }^{21}$ A mázsa rövidítése, amely $100 \mathrm{~kg}$.
} 
Az alábbi grafikonon Ferenc és Pál őszi és tavaszi gabonatermését összegeztem, és ezek átlagát is feltüntettem:

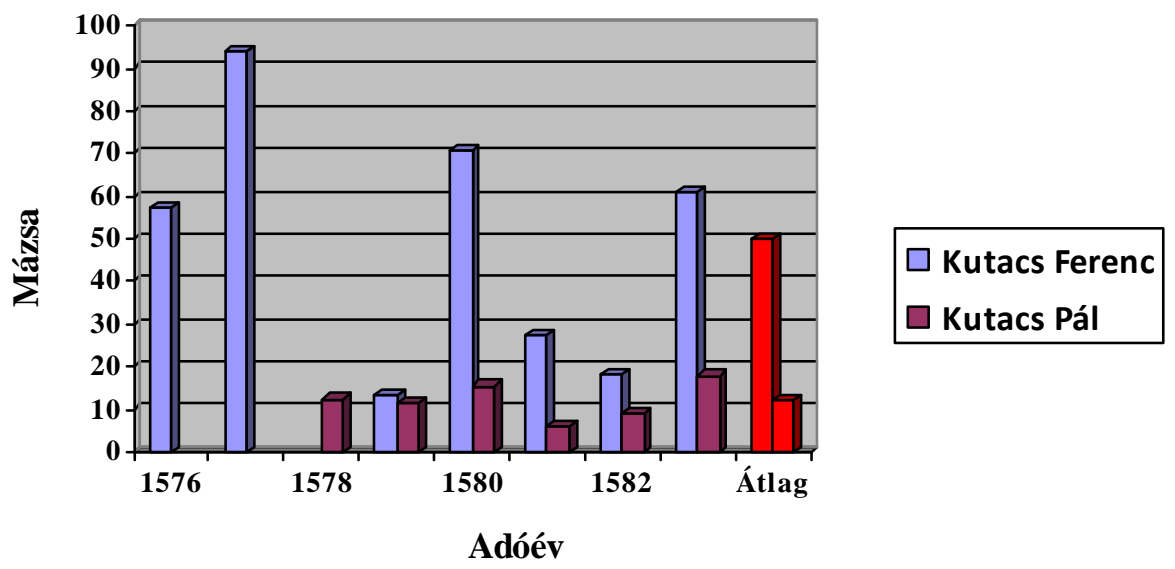

Kutacs Ferenc az említett hét évben összesen 505,125 gelima (303,075 q) őszi búzát termelt, ami átlagosan 72,16 gelimát (43,29 q) ad. A termésmennyiségek jelentős ingadozást mutatnak. Tavaszi gabonából az öt időpont alapján 65,25 gelima $(39,15$ q) az összes hozam, átlagban 13,05 gelima (7,83 q). Az őszi búza megtermeléséhez 14,43, míg a tavaszihoz 2,61 hold nagyságú szántóterületre lehetett szüksége. ${ }^{22}$ Ezeket összegezve 17,04 holdat kaptam, amely a gazda külső szántóterületének kétharmada. Ehhez hozzáadva az egyharmad kiterjedésü ugart (8,52 hold), amely így 25,56 holdnyi teleknagyságot eredményez.

Kutacs Pál esetében is elvégeztem ugyanezeket a számításokat. A rendelkezésre álló hat év adatai alapján összesen 118,687 gelima (71,212 q) az őszi termés, átlagban 19,781 gelima (11,86 q). Megtermeléséhez 3,95 hold szükségeltetett. A tavaszira vonatkozóan csak egy rendelkezésre álló adatom van: 1,8 gelima (1,08 q), ez 0,36 holdat feltételez. A szántóterület kétharmada tehát 4,31 hold, ugarral $(2,15$ hold), együtt pedig 6,46 hold.

Megállapíthatom, hogy Ferenc egy egész jobbágytelekkel bíró, módos gazda lehetett, erre a következtetésre jutott korábban N. Kiss István is. ${ }^{23}$ Pál vagyoni kategorizálása már nehezebb feladat. Öszi búza termése alapján, szántóterületének nagysága a negyedtelkesek közé esik. Továbbá az is kérdéses, hogy az 1548-ban felbukkanó Pál azonos lehet-e az 1578-1583 között szereplő személlyel. Az időbeli

\footnotetext{
${ }^{22}$ A számításhoz kapcsolódó kulcsot N. KISS ISTVÁN adja: „[...] számos 16. század végi kimutatásból s dézsma-összegezésböl tudjuk, hogy pl. Bihar megyében holdanként kb. 450 literes szemtermést vettek alapul. Ezek szerint kedvezö termés esetén az egy köblös vetömag ötszörösen térül meg. [...] 1 kassai gabona köböl kb. 1 kalangyával (30 kévés) egyenlö és a holdankénti 450 literes (3 mázsás) termés hozzávetölegesen 5 kalangyának felel meg." Lásd: N. KISS István: 16. századi dézsmajegyzékek : Borsod, Heves, Bereg, Bihar és KözépSzolnok megyék. Bp., 1960. 9.

${ }^{23}$ N. KISS: i. m., 234.
} 
közelség miatt elképzelhető. Elsőként a zsellérek sorában tünik fel, ami persze nem azt jelenti, hogy ö sem földdel sem igaerővel nem rendelkezett. Az 1578-ban szereplő Pál, - mint mondtam - ennél azért jelentősebb gazdasági erővel bírt. Ha ugyanarról a személyről van szó, akkor igyekszem az alábbiakkal magyarázatot adni.

Figyelembe kell venni, hogy a török terjeszkedés miként hatott a községre. Az 1553-as - vagyis az utolsó békeévből való - portális összeírásból megtudjuk, hogy Bolyokon 8 portát vettek számba. ${ }^{24} \mathrm{Az}$ 1554-es török támadást követöen 7 portát, 4 zsellért, 2 pusztult portát, és 1 bírót találtak itt az összeírók. Az 1555-ös év első felében „Bolyk deserta per turcam., - Bolyok a török miatt elhagyott. Az év második felében pedig csak 2 portát tüntettek fel. Az 1556-os évben a dicátorok három alkalommal szálltak ki összeírni a lakott helyeket. Első alkalommal Bolyok „,deserta” a másik két összeírásból pedig hiányzik. Portális összeírás ezek után csak 1564-ből ismeretes, melyben a környék falvai - így Bolyok is - hódoltként szerepelnek. A török iga alá kerülés azonban nem ekkor, hanem már 1554-et követően bekövetkezett. Ugyanis, ha végigtekintünk az 1555. november 15. és 1556. november 2. között összeírt hitetlenek fejadóján a Hatvani szandzsák területéhez tartozó Jászberényi náhijéban, akkor több környékbeli faluval ${ }^{25}$ egyetemben ott találjuk „Baloka” községet is, amely Salgó várához tartozott. ${ }^{26}$ Ebben az oszmánok hat háztartást írtak össze. Azonban a porták száma egészen a század végéig alacsony maradt: 1564-ben: 4 egészet és 6 pusztát, 1566-ban: 3, 1570-1572-ben: 2, 15741576-1578-1582-1584-ben: 1, 1588-ban: 2, 1596-ban pedig 2,5 portát; míg 1598ban 13, 1599-ben pedig 11 házat vettek lajstromba. Mindebből látható, hogy a település portaállománya és lakosainak száma is erösen lecsökkent.

A település birtokosai ${ }^{27}$ - a Bolyki család - minden bizonnyal igyekeztek megőrizni itt maradt jobbágyaikat, és közöttük újraosztva a település határában lévő megüresedett szántókat biztosították azok gazdasági alapját a jövőre nézve. Ezzel pedig fenn tudták tartani a maguk számára adózó képességüket. Mint ahogy az a török veszedelem előtti jegyzékekből kiderült, a család nem a zavaros időkben érkezett ide, hanem itt gyökereztek a középkor óta.

Ez alapján elképzelhető a két Pál közötti azonosság. Mivel a dézsmajegyzékekben Ferenc és Pál nem egymás után szerepel, hanem neveik között általában 4-6 más falubelit is megemlítenek, így ők nem egy telken éltek, hanem jobban elkülönülve a faluban. Már itt megfigyelhető a család két, vagyonilag és telek szempontjából is elkülönülő ága. A dézsmajegyzékek nem örökítik meg a családi kapcsolatokat, így nem alkalmasak genealógiai kutatásokra.

\footnotetext{
${ }^{24}$ MNL BAZML XV. 32. Dicális összeírások. 453. tek.

${ }^{25}$ Néhány szomszédos település: Disznós, Nádasd, Balaton, Cserne, Omán, Csokva, Sáta, Darofcse.

${ }^{26}$ LÁSZlÓFAlVI VeliCs ANTAL: Magyarországi török kincstári defterek. Bp., 1886-1890. 1. köt. 182.

${ }^{27} \mathrm{Az}$ 1549-es portális összeírások szerint a település birtokosai a következők: Bolyky Kálmán 1, Bolyky Jakab 1, Horváth Mátyás 2, Bolyky Márton 1 és Bolyky Péter 3 portával. A Horváth család csak zálogbirtokos a faluban. Lásd: MAKSAY FERENC: Magyarország birtokviszonyai a 16. század közepén. Bp., 1990. 260.
} 
Ferenc méhészkedéssel is foglalkozott, általában 2-3 kaptárral rendelkezett. Az irányadó számítást ${ }^{28}$ alapul véve ez nagyjából évi 12-18 kg-nyi (4,76-7,14 pint $\left.{ }^{29}\right)$ méztermést (95-143 dénár értékben $\left.{ }^{30}\right)$ produkált.

A család a 17. századból foghíjasan fennmaradt gabonadézsma-jegyzékekben is szerepel. 1601 és 1614 között kizárólag Kutacs Demeterrel találkozunk:

\begin{tabular}{|c|c|c|c|c|c|c|c|}
\hline $\begin{array}{l}\text { Sor- } \\
\text { szám }\end{array}$ & Adóév & Státusza & $\begin{array}{l}\text { Őszi } \\
\text { gabona } \\
\text { termés }\end{array}$ & Tized & $\begin{array}{l}\text { Tavaszi } \\
\text { gabona } \\
\text { termés }\end{array}$ & Tized & $\begin{array}{l}\text { Méhkas } \\
\text { (db) }\end{array}$ \\
\hline 1. & 1601 & bíró & - & - & - & - & - \\
\hline 2. & 1602 & adózó & - & - & - & - & $\begin{array}{cc}8 & (48 \\
\mathrm{kg} & \\
\end{array}$ \\
\hline 3. & 1604 & adózó & $\begin{array}{l}1 \mathrm{gl}^{31} \text { és } 2 \\
\mathrm{~m}(0,68 q)\end{array}$ & $\begin{array}{c}3 \mathrm{~m} \\
(0,06 \mathrm{q}) \\
\end{array}$ & - & - & $\begin{array}{cc}6 & (36 \\
\mathrm{kg}) & \\
\end{array}$ \\
\hline 4. & 1605 & bíró & - & - & - & - & - \\
\hline 5. & 1606 & adózó & - & - & - & - & $\begin{array}{ll}11 & (66 \\
\mathrm{kg})\end{array}$ \\
\hline 6. & 1608 & adózó & $\begin{array}{l}6 \mathrm{gl} \text { és } 22 \\
\mathrm{~m} \\
(4,27 q)\end{array}$ & $\begin{array}{l}19 \mathrm{~m} \\
(0,38 \mathrm{q})\end{array}$ & - & - & $\begin{array}{cc}2 & (12 \\
k g) & \end{array}$ \\
\hline 7. & 1609 & adózó & $\begin{array}{l}11 \mathrm{gl} \text { és } 10 \\
\mathrm{~m} \\
(9 q)\end{array}$ & $\begin{array}{l}1 \mathrm{gl} \\
(0,8 q)\end{array}$ & $\begin{array}{l}0,85 \mathrm{gl} \\
(0,68 q)\end{array}$ & $\begin{array}{l}3 \mathrm{~m} \\
(0,06 q)\end{array}$ & $\begin{array}{cc}3 & (18 \\
k g) & \end{array}$ \\
\hline 8. & 1614 & bíró & - & - & - & - & - \\
\hline
\end{tabular}

Vezetéknevüket - nyelvtani és névírási szabályok híján - általában Kuttas-nak, Kutasi-nak írták, később előfordul a Kutacz (1620), Kutas (1622) alak is. Demeter termelvényeinek mennyisége a zsellér-pauper kategóriák határán mozgott.

Az 1619 és 1627 közötti időben Kutacs György tủnik fel. ${ }^{32}$ Gazdasági ereje az előbbiekhez hasonló. ${ }^{33}$

\footnotetext{
${ }^{28} \mathrm{~N}$. KISS ISTVÁN kutatásai alapján a XVI. századi termelési viszonyoknak megfelelően átlag 6 kg-os értékkel számoltam. Ô ekképp foglalja össze: „Kiindulva a 394 kasból, kb. évi 20 mázsás mézterméssel számolhatunk. Egy méhészetre átlagosan évente $12 \mathrm{~kg}$ méz esik. [...] 46 kas után, a termés felét számítva eladásra kerülö mennyiségnek, évi 1,5 mázsára becsülhetjük az áruméz minimális súlyát.” Lásd: N. KISs: i. m., 243.

${ }^{29} \mathrm{Az}$ átváltásról: 1 liter méz $=1,5 \mathrm{~kg}, 1$ régi budai és az új pozsonyi pint nagysága $=1,6786$ liter. Ennek megfelelően 1 pint egyenértékü 2,5179 kg mézzel.

${ }^{30}$ BodNÁR TAMÁs: Borsod vármegye adózása a török korban. Miskolc, 2005. Innen az alábbi részletek: Centerben: „Vajat 1 pintet adunk, mézet ugyanannyit, ami kitesz 40 dénárt.” (20.); Sátán: „Vajat tíz pintet adtak, mézet is ugyanennyit, ami kitesz 4 forintot.” (30.); Arlóban: „Vajat 20 pintet adtak, ami kitesz 4 forintot.” (31.); Járdánházán: „Vajat adtak 1 pintet, ami kitesz 20 dénárt.” (31.); Ózdon: „Vajat 2 pintet adtak és mézet is ugyanannyit, ami kitesz 80 dénárt.” (38.). Ennek megfelelően egy pint méz árát 20 dénárral számoltam.

${ }^{31}$ Mint az a dézsmajegyzékekből kiderül, 1601 és 1609 között áttértek a 32 kévét tartalmazó gelimára. 1609-ben 40-el, 1616-ban 32-vel, 1619-ben 30-al, 1620-1621-ben 40-el, 1622-ben pedig 30-al tették azt egyenértékűvé.
} 
1627-ben Áfra Albert és Kutacs Pál volt a falu bírája (judex). 1647-ben Kutacs Tamás és Pál tünik fel ismét. 1660-1661-ben Balázs és Imre. 1662-1665-ig Kutacs Imre a község elöljárója. 1662-ben Benedek adózik, 1663-ban 4 méhkas után (a váltság összege még ekkor is 2-2 dénár). 1664-ben pedig ugyanő 2 méhraj és 4 kecske (capra) után fizetett (a kecskéknek 6-6 dénár a váltsága). 1672-ben a decimátorok csak 5 zsellért találtak a faluban, és megjegyezték: „Ex integris quatuor curiis venerunt et dicebant quod nec nobiles nec rustici decimam istius pagi dederunt.” - „Az egészből [ti. a faluból] négy szekérnyi [gabona] jött be, és azt mondták, hogy ennek a falunak sem nemesei sem parasztjai tizedet nem adtak."

1673-1674-ben a zsellérek mellett összeírták az armalistákat is, megjegyezve, hogy: „Ezek semmiből sem adtak decimát...” Az eredeti sorrendnek megfelelően: Kutacs Imre, Veres Pál és Balázs, Császár Farkas, Bolyki ${ }^{34}$ Tamás és Albert, Kispál Pál és Mustos Péter.

Bolyok község tehát a 17. századi nemesítések hatására kezdett kuriálissá válni, és egy rövid elnéptelenedési (desolata) időszakot követően, ${ }^{35}$ 1689-től ténylegesen annak tekinthető. Ekkor feljegyezték: „Possessiones Jardanhaza Oomány et Bulik sunt curriae nobilitares neque segetes habent[ur].” - „Járdánháza, Omány és Bolyok falvakat és a szántóföldeket is a kurialista nemesek birtokolják."

Mint láttuk, az 1660-as évek elején tünik fel a jegyzékekben Kutacs Imre, aki folyamatosan a falu bírájának tisztét töltötte be. E hivatalának köszönhetően mentesült a tized, és a dicalis adó megfizetése alól. ${ }^{36}$ Így gazdasági erejét nem tudtam felmérni. Valamint azt sem, hogy a mondottak közül kivel állt közvetlen családi kapcsolatban. A 17. század első feléből származó jegyzékek csekély gazdasági erőt, és ezzel párhuzamosan alacsony adóösszegeket mutatnak. Felmerül a kérdés, hogy milyen anyagi forrásból tudták előteremteni a jobbágyi terhek alól történő felszabadítás (manumittálás), a nemeslevél folyamodásának és magának az oklevél kiállításának költségeit (taxáját) ? ${ }^{37}$ A 16. századi dézsma és kilenced szedési gyakorlat, és annak mértéke mit sem változott a 17. században. A töröknek fizetendő adók azonban fokozatosan emelkedtek. Erről tanúskodnak az Eszterházy Miklós nádor rendeletére elkészített - többek között - Borsod vármegye hódolt településeinek adó- és kár összeírásai is. ${ }^{38}$ Az 1641. évi vizsgálat jegyzőkönyvében a Bolyok faluban élö, 48 éves Veres Benedek - aki Bolyki Bálint úr jobbágya volt esküdt ekképp vallott: „Az miolta reá emlékezem, az időtül fogván tizedet adtunk az

\footnotetext{
${ }^{32} \mathrm{Az}$ alábbi évek jegyzékeiben fordul elő: 1619, 1620, 1621, 1622, 1623, 1624, 1626 és 1627.

${ }^{33} 1619$-ben 13 gelima és 15 kéve öszi búzája, tavaszija pedig 1 gelima és 4 kéve termett. E mellett 3 méhrajjal (examen) bírt. 1620-ban 8 gelima és 17,5 kéve öszi, valamint 2 gelima 10 kéve tavaszi az adó alapja. Ekkor 2 kaptára volt. 1622-ben 6 dénár kereszténypénzt fizetett.

${ }^{34}$ Boliki alakban.

${ }^{35}$ A dézsmajegyzékekben 1683-ban a korábbiakhoz hasonlóan összeírták a települést, 1686ban elhagyottként (desolata) szerepelt, 1688-ban pedig az egész környék néptelen volt. 1689ben már teljes egészében kuriális.

${ }^{36}$ ILA BÁLINT: Gömör megye I., a megye története 1773-ig. Bp., 1976. 285.

${ }^{37}$ KÓTA PÉTER: A címereslevél ára. Mágnások, birtokosok, címerlevelesek : konferencia : Pécsvárad, 1995. szept. 12-13. Szerk.: ÓDOR IMRE. Debrecen, 1997. 149-156. pp.

${ }^{38}$ BODNÁR: i. m., 8.
} 
töröknek, de elejin csak az igaz tized volt. Szolgálatunk csak igen kevés volt. Mostan szántásunknak, kaszálásunk[nak], széna-, fa-, búzahordásunknak, aratásunknak semmi rendi nincsen, hanem egész esztendö által szolgáljuk, szölöjét míveljük. Egy forintot ad minden barmos ember, az zsellér denarios 50. Ez mellett négy-négy icce vajat, az kinek marhája vagyon, ad." 39 A század első felében is meglévő, de a török kiüzésével párhuzamosan felerősödő hadjárások sem kedveztek a vidék jobbágynépességének.

A tizedjegyzékek - ez esetben - tájékoztatnak a família társadalmi helyzetében bekövetkezett változásról. Ugyanis 1669-ben, más - nemességet szerzett családokhoz hasonlóan a Kutacsok is mentesültek a különféle adók és szolgáltatások alól, és beléptek a nemesi rend tagjainak sorába, így a további jegyzékekből jobbágyként hiányoznak. A família felszabadító levelét az Egri Káptalan hiteleshelyi levéltára őrizte meg az utókor számára (2. kép). ${ }^{40}$

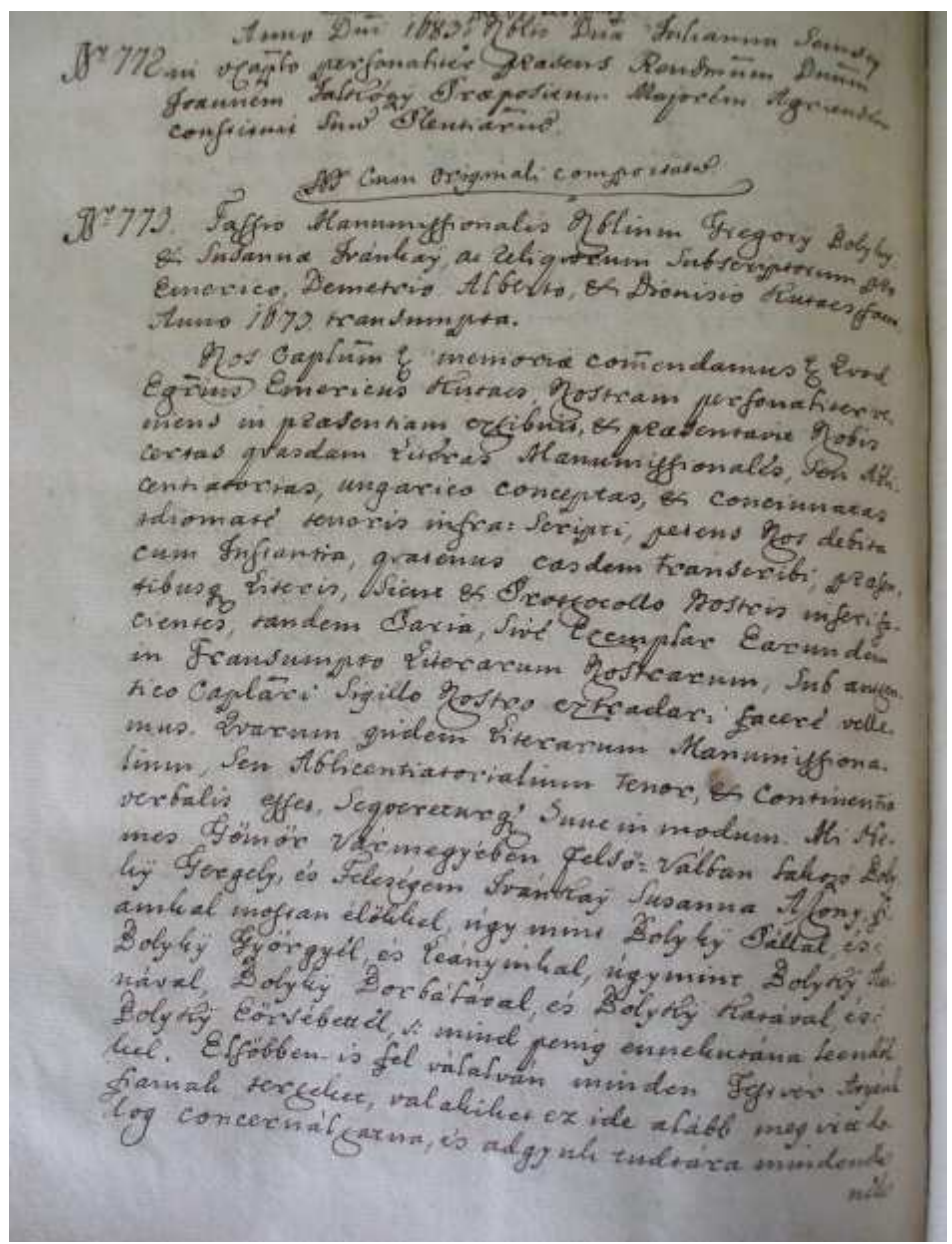

2. kép. Az Egri Káptalan jegyzőkönyve.

\footnotetext{
${ }^{39}$ BODNÁR: i. m., 158.

${ }^{40}$ MNL Heves Megyei Levéltára, XII. 1. 547-549.
} 
Bolyky Gergely és Ivánkay Zsuzsanna szabadon bocsátási bevallást tett Kutacs Imre, Demeter, Albert és Dénes részére. Mindezt 1673. június 13-án ${ }^{41}$ az egri káptalan „tekintetes” Kutacs Imre személyes kérésére a jegyzőkönyvbe másolta, és részére másolatot adott ki (lásd a Függelékben: 1.).

A felszabadító levélből látható, hogy a Bolykyak mentesítették a Kutacs család tagjait és telküket a jövőre nézve mindenféle földesúri tehertől (inscriptio és exemptio). Ennek költsége 700 Forint, egy csikó és egy pár karmazsin csizma volt. A Borsoddal szomszédos Abaúj vármegyében kelt 1669. december 10-i árszabásban olvasható, hogy abban az időben egy hízott magyar ökör 40, míg egy jobb fajta csizma 3 forintba került. ${ }^{42}$

Címerkérő folyamodványuk nem maradt fenn. I. Lipót magyar király (16571705) ennek, a már említett Kutacs Imrének nemességet és címert adományozó oklevelet adott ki Bécsben, 1669. október 29-én (lásd Függelék: 2.). ${ }^{43}$ Az oklevél felhajtásának (plicatura) jobb szélén olvasható a kihirdetési záradék (3. kép).

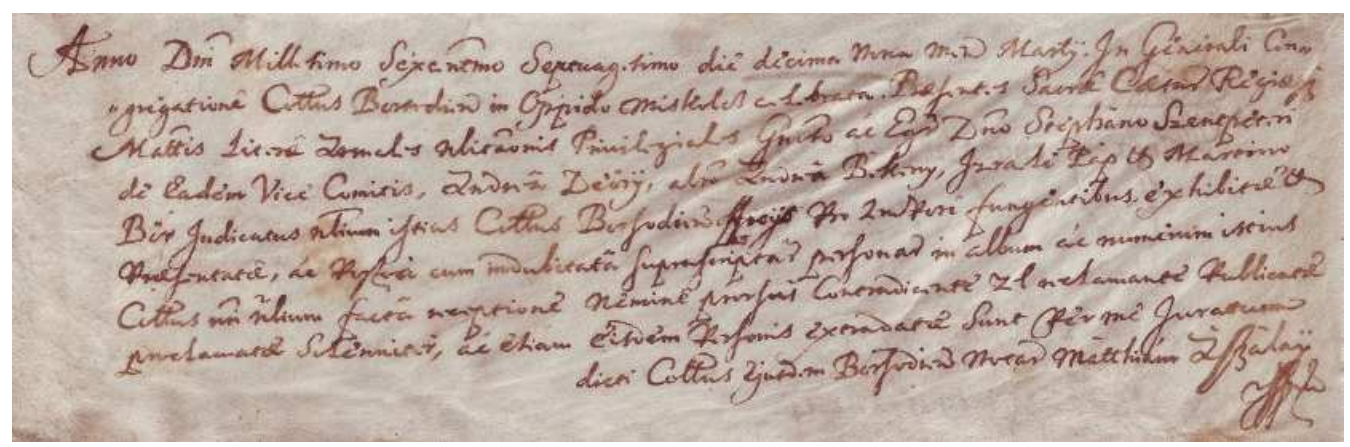

3. kép. Kihirdetési záradék.

Borovszky Samu is megemlíti, hogy a família 1669. október 29-én nyert címert és nemességet, és felsorolja az adományosokat: „Kútats Imre, neje: Balaspali Margit, fia: Dénes, leánya: Orsolya; testvérei: Demeter és Albert, ezek nejei: Szalmási Katalin és Vas Dorottya, ennek fia: Albert, leányai: Anna, Erzsébet, Zsófia, Katalin és Dorottya. (Jk. VIII. 407.)."44 Az újrakötött vármegyei jegyzőkönyvben ma az újraszámozás alapján a 423. oldal alján található a bejegyzés.

\footnotetext{
${ }^{41}$ „Datum feria tertia proxima post dominicam secundam sacro sanctae et individuae trinitatis. Anno D[omi]ni millesimo sexcentesimo septvagesimo tertio."

${ }^{42}$ ACSÁdY IGNÁCZ: Régi árviszonyok. Magyar Gazdaságtörténelmi Szemle. Szerk.: PAIKERT ALAJOS. Bp., 1894. (1. évf.) 1. sz. 88. és 90.

${ }^{43} \mathrm{Az}$ eredeti oklevél a mai napig magántulajdonban van. Örzője Veres Pálné, született Kutacs Ilona, aki ózd-bolyoki lakos. A latin szövegben szereplő rövidítéseket jelölés nélkül oldottam fel. Az oklevél arany színnel írott szavait dölt, a vörös tintával pergamenre vetetteket pedig félkövérrel szedéssel jelöltem.

${ }^{44}$ BOROVSZKY: i. m., 237.
} 
Kempelen Béla is Borovszkyra hivatkozva ugyanezeket az adatokat közli. ${ }^{45}$ A Királyi Könyvek nem tesznek említést a családdal kapcsolatosan. ${ }^{46}$

$\mathrm{Az}$ armális jó állapotban vészelte át az évszázadok viszontagságait (4. kép). A pergamen még mindig erős, halvány sárga árnyalatú, mérete: 496 x 737 mm. A plicatura 160, a címerkeret magassága 168, szélessége pedig $125 \mathrm{~mm}$.

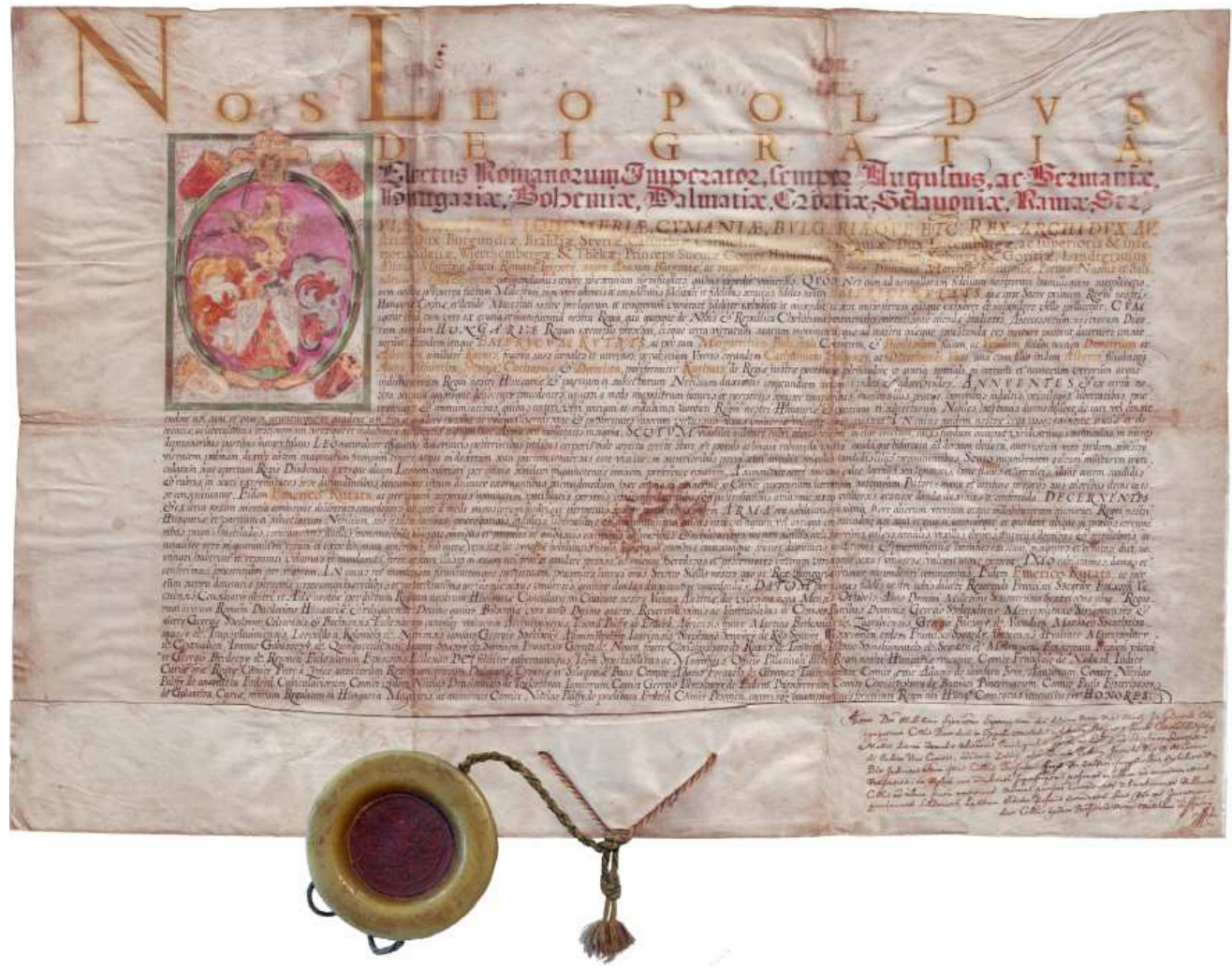

4. kép. A Kutacs család armálisa.

Ázás, vagy sérülés nyomai nem láthatók rajta. A plicaturát vörös-sárga-kékfehér színủ sodrott zsinór fogja össze, melyen ép, viasz függőpecsét lóg. A $116 \mathrm{~mm}$ átmérőjü, cipóformájú, természetes színü (enyhén sárgás-barnás), magas peremü viaszfészekbe került az uralkodó, kancellárián őrzött pecsétjének vörös viaszba nyomott képe.

Az adományosok nevének felsorolásánál - nyelvtani szabályok híján - eltérés figyelhető meg a családnév írásában. Amíg a legtöbb helyen Kutats alakban fordul elő, egy helyütt Kuthats-ként szerepel.

${ }^{45}$ „Czímeres levelet 1669. okt. 29. K. Imre kapott. Kihirdette Borsodmegye." Lásd: KEMPELEN BÉLA: Magyar nemes családok. Bp., 1913. 6. köt. 305.

${ }^{46}$ KIRÁLYI KÖNYVEK: [elektronikus dokumentum]. Közreadja a: Magyar Országos Levéltár, Arcanum Adatbázis. Bp., 2000-2002. 10-17. köt. (1647-1683). 
Lássuk a címerkeret leírását: arany-zöld keretben a rózsaszín damaszkolt szőnyeg felső részén központi helyet foglal el Ausztria címere a koronával, a keret négy sarkában, egy-egy címert találunk (Magyarország kiscímere, illetve Csehország, Horvátország és Dalmácia címere), ezen belül látható a zöld babérkoszorú által övezett lila mezőben elhelyezkedő címer. Az országok címere alig kidolgozott, ábrái szinte kivehetetlenek, színei elmosódottak. Dalmácia jelvényén csak a három sárga folt jelzi a három koronás oroszlánfejet.

A szövegben részletesen leírt címerképhez is van néhány észrevételem. A katonai pajzs nem háromszögü, hanem kerektalpú. Az oroszlán jobb mancsában lévő szablya nem látható a pajzs süvegezése miatt, amelyről nincs szó a szövegben, és nem is festették be, valamint a rajta látható liliomoknak is csak ceruzás körvonalai vannak meg. A sisakdísz oroszlánja teljességével azonban pótolja hiányérzetünket. A foszlányok leírása - ,innen aranysárga és kék, onnan pedig fehér és vörös” - és ábrázolása között annyi különbség van, hogy az aranysárga mellől hiányzik a kék.

Érdekes momentum, hogy a címerszerző Imre minden bizonnyal testvéreivel együtt élt a községben, azok is nősek voltak, sőt Albert már családos, mégsem találjuk meg a nevüket a dézsmajegyzékekben, és fordítva sem a többiekét az armálisban.

A nemesi levél számos családtag nevét megőrizte az utókornak. 1695-től kezdődően már vizsgálhatók a Sajóvárkonyi plébánia anyakönyvei. Ugyanis Bolyok község a török-kor viszontagságai közepette, 1620 -tól ennek filiája volt. ${ }^{47}$ Az első, korai időkből fennmaradt matricula még nem táblázatos felépítésű, mint későbbi társai, hanem szövegesen, latin formulákra építve, folytatólagos bekezdésekkel vezetett.

A töredékesen megmaradt címoldalon találjuk velük kapcsolatosan az első, keresztelésre vonatkozó bejegyzést: „1695. augusztus 28. Megkereszteltem a Pál néven született csecsemőt, [akinek szülei]: [...] és Kutacs Orsolya. Keresztszülök voltak: Gergely $[\ldots]^{, 48}$ (5. kép).

\footnotetext{
${ }^{47}$ KOVÁCS-VERES TAMÁs GERGELY: Bolyok község históriája a török-kor első felében 15261606. Bp., 2013. 66.

${ }^{48}$ „Baptizavi inf[a]nte[m] n[omi]ne Paulu[m] natu[m] ... [ex parentibus] ... et Ursula Kutacs patrini fuerunt Gregori ...” Lásd: Az Ózd-Sajóvárkonyi Plébánia anyakönyvei, 16951950. ANYAKÖNYVEK, 1. köt. (1695-1737) címlap.
} 


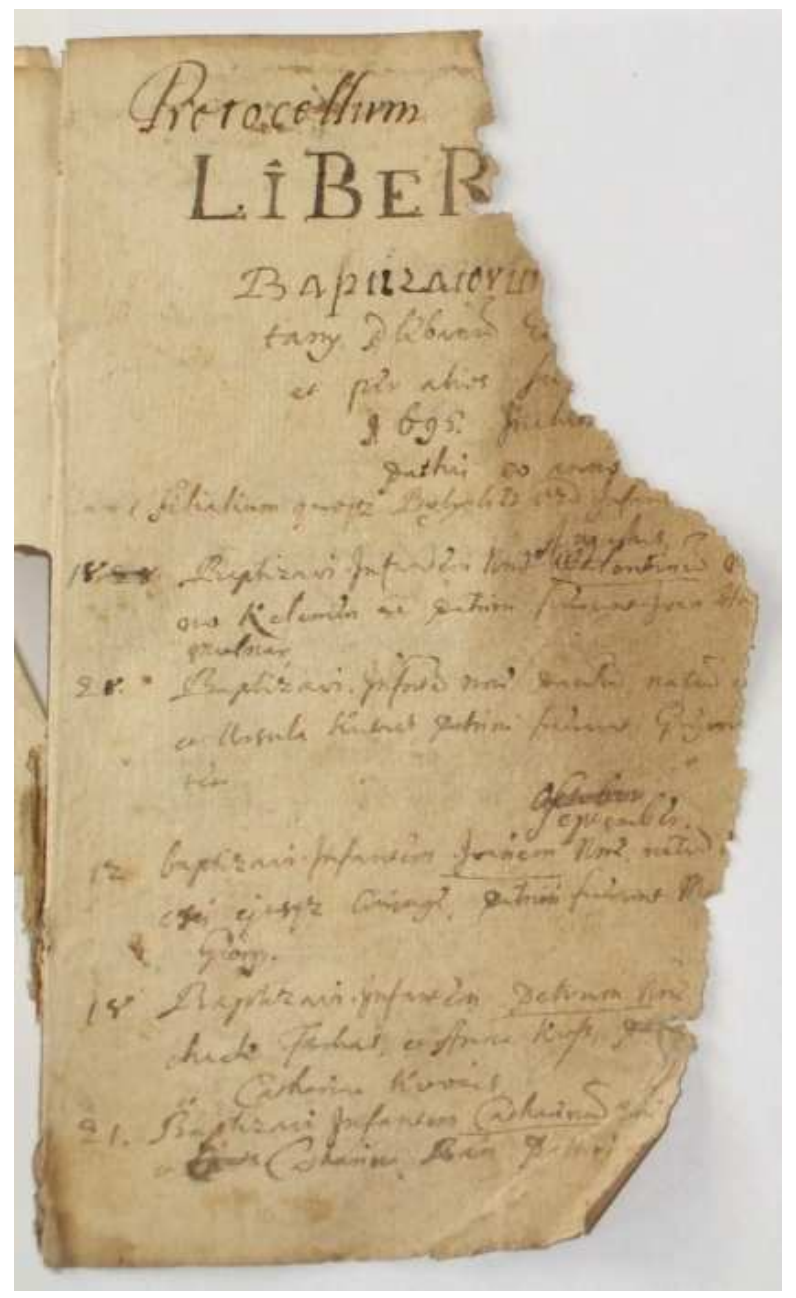

5. kép. Az I. anyakönyvi kötet címlapja.

Orsolya asszony nem más, mint a nemességszerző Imre lánya, aki Pál nevü fiának adott életet, sokadikként ezen a néven a famíliában. 1697. december 2-án, 1699. július 1 -jén ${ }^{49}$ és 1707 . november 9-én keresztanyaságot vállalt. ${ }^{50}$

\footnotetext{
${ }^{49}$ A dátum kérdéses, ugyanis a bejegyzés május és augusztus hónapok között található, eléje mégis 17 bris került. A bejegyzés írója talán az év hetedik hónapjára, azaz júliusra gondolt? ${ }^{50}$ „Baptizavi inf[ante]m n[omi]ne Elizabetha[m] ex pa[ren]tib[us] Kiss Mátyás et Anna Demeter patrini Joannes Csaszar et Ursula Kutacs.” Valamint: „Baptizavi infantem n[omi]ne Dorotheam ex parentibus Casparo Enekes et Catharina Nemet patrini Paulus Mihály et Dorothea Kutacs.” Illetve: „Baptizavi infantem adm[odum] r[everen]dus d[omi]n[us] Joannes Szöllösi nomine Francisc[um] natu[m] ex parentib[us] Petro Kovács Judita matri patrini Gregor[ius] Hangoni Ursula Kutacs. Bolyok.” Lásd: ANYAKÖNYVEK: i. m., 7., 10-11., és 34.
} 
Meg kell jegyeznem, hogy a születés és a keresztelés időpontja nem esett egybe, a köztük eltelt idő néhány nap esetleg egy-két hét is lehetett. Ez érvényesül az egyes személyek elhunyta, és temetésének időpontja esetében is.

1696. július 20-án, 1701. december 14-én illetve 1704. december 25-én Vas Dorottya legkisebb lánya, Dorottya tünik fel, mint keresztszülő. ${ }^{51}$ Majd a későbbiekben még két alkalommal. ${ }^{52}$ 1697. augusztus 11-én - az ekkor 43 év körüli - Kutacs Béla viseli e tisztet, ám ő a család másik ágának tagja lehetett, mivel az adományozottak felsorolásában nem szerepelt. ${ }^{53}$

A bejegyzések itt a lakóhelyet - Bolykiensis-Bolyok - is meghatározták és megtudjuk, hogy a család római katolikus felekezeten volt.

1699. augusztus 24-e előtt néhány nappal látta meg a napvilágot Császár János, - aki maga is armalista volt - és Kutacs Orsolya, Imre nevü fia. ${ }^{54}$ Majd mindketten keresztszülők 1700. augusztus 15 -én. ${ }^{55}$

A házasságkötésekre vonatkozó adatok között e korai anyakönyvben nem találtam utalást a családra. Az elhunytakra vonatkozóak között azonban igen: „1724. június 6. Bolyokon eltemettem a Kutacs Anna [nevü] gyereket, 6 éves [volt]., 56

A címerszerző unokája - Imre - fiatalon hunyt el: „1727. december 4. Eltemettem a boly[o]ki Kutacs Imrét, a legszentebb bünbánattal, az utolsó kenettel és az oltáriszentséggel megerősítve." ${ }^{57}$ Abban az időben csak hozzávetőlegesen adták meg az egyes személyek életkorát. Hiszen sok esetben még nem álltak

${ }^{51}$ „Baptizavi inf[an]tem n[omi]ne Dorothea[m] e[x] Casparo Kovats et Catharina Pamutos parentibus, patrini Casparus Enekes et Dorothea Kutacs.” Valamint: „Baptizavi infantem n[omi]ne Elizabetha[m] nata[m] ex parentib[us] Matthia Veres et Ursula Ipacs patrini fuerunt Mathaeus Hagyo et Dorothea Kutacs.” Illetve: „Baptizavi infantem filium Gaspari Enekes ex matre Catharina Nemet cui impositu[m] nomen Stephanu[s], patrini ejus Michael Páll et Dorothea Kutacs." Lásd: ANYAKÖNYVEK: i. m., 4., 17., és 24.

${ }^{52}, 1710$. június 8. Baptizavi infantem no[min]e Stephanu[m] ex parentibus catholicis Stephano Csák et Anna Havas patrini ego plebanu[s] Steph[anus] Páldi Varkon[iensis] et Dorothea Kutacs. Uraienses.” Valamint: „1710. december 10. Baptiz[avi] infantem no[min]e Stephanu[m] natu[m] ex parentib[us] catholicis Mathia Veres et Ursula Ipacs. Patrini fuere Martinus Bolyki et Dorothea Kutacs. Cathol[ici] Bolykienses." Lásd: ANYAKÖNYVEK: i. m., 43-44.

${ }^{53}$ „Baptizavi infantem n[omi]ne Paulu[m] Disznosdiensem ex par[enti]b[us] Francisco Kovats et Anna Marcis patrini ejus fuerunt Andreas Toth et Helena Kutacs." Valamint: „Baptizavi infan[tem] n[omi]ne Steph[anum] ex pare[nti]b[us] Thoma Boda et Catharina Antal patrini Adalbertus Kutacs et Elizabetha Veres." Lásd: ANYAKÖNYVEK: i. m., 5. és 7.

${ }^{54}$ „Baptizavi infantem n[omi]ne Emericu[m] ex parentib[us] Joanne Csaszar et Ursullya Kutacs patrini ejus fuerunt Lukas(?) Csik et Elizabetha Jeso.” Lásd: ANYAKÖNYVEK: i. m., 11.

${ }^{55}$ „Baptizavi infante[m] n[omi]ne Laurentium natum ex parentib[us] Joanne Medve et Catharina Guszona. Patrini fuerunt Joannes Csaszar et Ursula Kutacs." Lásd: ANYAKÖNYVEK: i. m., 14.

${ }^{56}$ „Sep[elivi] inf[antem] Anna[m] Kutács in Bollyk 6. an[n]or[um].” Lásd: ANYAKÖNYVEK: i. m., 154.

${ }^{57}$ „Sep[elivi] Emericum Kutacs Bolykien[sem] s[anctis]simis poeni[tenti]ae, [et] euch[a]ri[sti]ae et extremae unct[ionis] sacramentis munitum. An[n]or[um] cir[citer] 34." Lásd: ANYAKÖNYVEK: i. m., 157. 
rendelkezésre korábbi anyakönyvek, vagy egyéb források. Viszont - mint láttuk már Imre születése előtt is vezették az anyakönyvet, így ha a plébános vette volna a fáradtságot, pontosan is beírhatta volna, hogy az elhunyt 28 éves volt.

A család másik ágának egy tagja esetében azonban pontos életkort közöl: „1729. január 2. Eltemettem Kutacs Béla boly[o]ki lakost, a legszentebb bünbánattal és az oltáriszentséggel megerősítve. 75 éves volt." ${ }^{, 58}$

A magyar névviselés az európai mintákhoz hasonlóan fejlődött, és szabályozására nézve három korszakot különíthetünk el. Az első időszakban - a honfoglalás korától kezdve a felvilágosult abszolutizmus időszakáig - még nincsenek - vagy csak elvétve - a nevek viselésére vonatkozó szabályok ${ }^{59}$ Mint láthattuk, a nemességszerző Imre lánya, Orsolya Császár Jánossal kötött házasságot. Azonban nem vette fel annak családnevét. A mellékelt bejegyzésekből is kitünik, hogy ez általános volt a korszakban, hiszen a házastársakat a frigy elött és után is a korábbi nevükön említették. Azonban más aspektusa is van ezen névviselésnek. Főként azok a családok, melyek nemeslevéllel kerültek nemesítésre, jogaikat azon keresztül tudták érvényesíteni és fenntartani a jövőre nézve. Az armális megörzésével párhuzamosan az abban szereplö családnevet is folyamatosan viselniük kellett. Hiszen, ha házasság, vagy más úton megváltozott, akkor később már nehezen tudták bizonyítani nevüket és leszármazásukat a címerszerzőtől. Tehát az adott családnév folyamatos viselése és öröklődése által kapcsolódtak a nemességhez. Kivált fontos szerepe volt ennek egy olyan korszakban, mikor folyamatosan napirenden voltak a nemességvizsgálatok majd a nemességi perek.

III. Károly magyar király (1711-1740) 1723. április 10-én kelt rendelete alapján megindultak hazánkban a nemességvizsgálatok (investigatio nobilium). Az eljárást a vármegye által kijelölt megyei tisztségviselőkből felállított biztosság folytatta le, melynek eredményét a vármegye jegyzökönyvébe is bevezették. ${ }^{60}$ Hiszen a nemesi vármegye törvényhozással, végrehajtással és igazságszolgáltatással kapcsolatos politikai funkciókat is magában hordozott. Az 1728. március 15-én lezajlott investigatio során Bolyokon a Kovácsok, Veresek és Császárok mellett a Kutacs família is prezentált: „Béla és Mihály, Kutacs [Imre] unokája, a Lipót által Bécsben, 1669. október 29-én kiadott [oklevelet] Borsod vármegye nemesi közgyủlésén 1670. március 19. napján kihirdették. Kutacs Imrének, általa feleségének Baláspály Margitnak és fiának Dénesnek és lányának Orsolyának, ezen keresztül Demeternek

\footnotetext{
${ }^{58}$ „Sepel[ivi] Adalbertum Kutacs incola[m] Bollykien[sem] s[anctis]simis poeni[tenti]ae, et euch[a]ri[sti]ae sacramentis munitu[m]. An[n]or[um] 75.” Lásd: ANYAKÖNYVEK: i. m., 158.

${ }^{59}$ Megyeri-PÁlfFi ZoltáN: Név és jog, a névviselés jogi szabályozásának fejlödése Magyarországon. Bp., 2013. 23.

${ }^{60}$ SZÁLKAI TAMÁS: Iratok és armalisták. Mủveltség és mentalitás a bihari nemességigazolások dokumentumaiban. Hajdú-Bihari Levéltári Füzetek 1. Debrecen, 2010. 4-5. Lásd még: PAPP LÁSZLó: Az önkormányzatiság vázlatos áttekintése, különös tekintettel a hosszú 19. század alkotmányos megoldásaira. De iurisprudentia et iure publico: jog- és politikatudományi folyóirat. Főszerk.: PACZOLAY PÉTER. Szeged, 2012. (VI. évf.) 1-2. sz. 1. és PAPP LÁSZLÓ: The concept of autonomous local governments and their different forms of appearances in the traditions of our national public law. Journal on European History of Law. EU, 2012. (Vol. 3) No. 1. 62-65.
} 
és Albertnak, akik szintén Kutacs testvérek, kiadatott, az adományossal való kapcsolattal semmilyen nehézség nem merült fel. Továbbá ugyanazok feleségeinek: Szalmássi Katalinnak és Vas Dorottyának, az ő fiának Albertnek, és leányainak: Annának, Erzsébetnek, Zsófiának, Katalinnak és Dorottyának, akik hasonlóan Kutacsok.",61

1725-ben a taksás nemesek (taxalistae) községenkénti összeírása során találkozunk - többek között - Kutacs Imrével, aki féltelkesként tűnik fel. ${ }^{62}$ Ugyanis az 1595. évi V. törvénycikk meghagyta, hogy: „, [...] az egytelkes nemesek, [...] adózzanak és hadcsapatokat állítsanak ki." ${ }^{\circ 3}$ A hadiadót a 16-18. században taxának is nevezték, melyet a jobbágytelken élő kisnemeseknek is fizetniük kellett. ${ }^{64}$ A tized fizetésére is rászoríthatták őket. ${ }^{65} \mathrm{Ez}$ azonban nem jelenti a nemesi adómentesség eltörlését.

Az 1754-1755. évi vármegyei nemesi összeírás 2228 kiváltságos személye (jogi és természetes) között azonban nem szerepeltek a Kutacsok. ${ }^{66}$

Bolyok urbáriuma 1771. június 18-án készült el, ennek tabellájában Beretki Zsigmond úr jobbágyaként Kutacs Imrével találkozunk. ${ }^{67}$ Nyolcad méretü jobbágytelekkel, negyed pozsonyi mérőre való beltelekkel, 4 hold szántóval, és 1 embervágó réttel rendelkezett. A robotot 2 marhával (igával) kellett elvégezni 6 és fél nap időtartamban, vagy 13 napig gyalogosan. Kilenced helyett heted jár a földesúrnak természetben, valamint lenböl és kenderből. Ezeken kívül 1 Forinttal, negyed icce ${ }^{68}$ vajjal (2,09 dl), negyed-negyed kappannal és csirkével illetve másfél tojással adózott. Ố láthatóan a Kutacs család nemesi ágán kívül rekedt (6. kép).

\footnotetext{
${ }^{61}$ „Adalbertus et Michael nepos ejus Kutacs, Leopoldinas Viennae 29 8bris 1669 ema[na]t[as]. Publicat[us] in co[mi]t[a]t[u] Borsodien[si] sub g[ene]r[a]li congreg[atione] die 19 martii 1670. Pro Emerico Kutacs per illum Margareta Balaspaly consorte et Dionisio filio ac Ursula filia, hocpro Demetrio et Alberto similit[er] Kutacs fratribus emanatae cum ipse impetrator fuisset nulla difficultas, et pro etiam uxoribus eund[em] Catharina Szalmassi ac Dorothea Vas una cu[m] filio eisdem Alberto, filiabusq[ue] Anna Elisabetha Sophia, Catharina Dorothea pariformiter Kutacs.” Lásd: MNL BAZML IV. 516. No. 1281.

${ }^{62}$ MNL BAZML IV. 501/a. 20. köt., 213.

${ }^{63}$ Ezer év törvényei: http://www.1000ev.hu/index.php?a=3\&param=2710 (a letöltés ideje: 2014. január 7.).

${ }^{64}$ BÁN PÉTER: Magyar történelmi fogalomtár. Bp., 1989. II. köt. 196.

${ }^{65}$ Magyar Katolikus Lexikon: http://lexikon.katolikus.hu/T/taksás nemesek.html (a letöltés ideje: 2014. január 8.).

${ }^{66}$ MNL BAZML IV. 501/b. Politicorum actorum materiae XXVII. fasc. XXXI. frust. 1019.

${ }^{67}$ MNL BAZML IV. 501/b. Közgyülési iratok. XXII. I. 325.

${ }^{68} 1$ pozsonyi (híg) icce 1593 és 1874 között 0,8393 literrel volt egyenértékü. Lásd: BoGDÁN ISTVÁN: Magyarországi ür-, térfogat-, súly-és darabmérték 1874-ig. Bp., 1991. 208.
} 


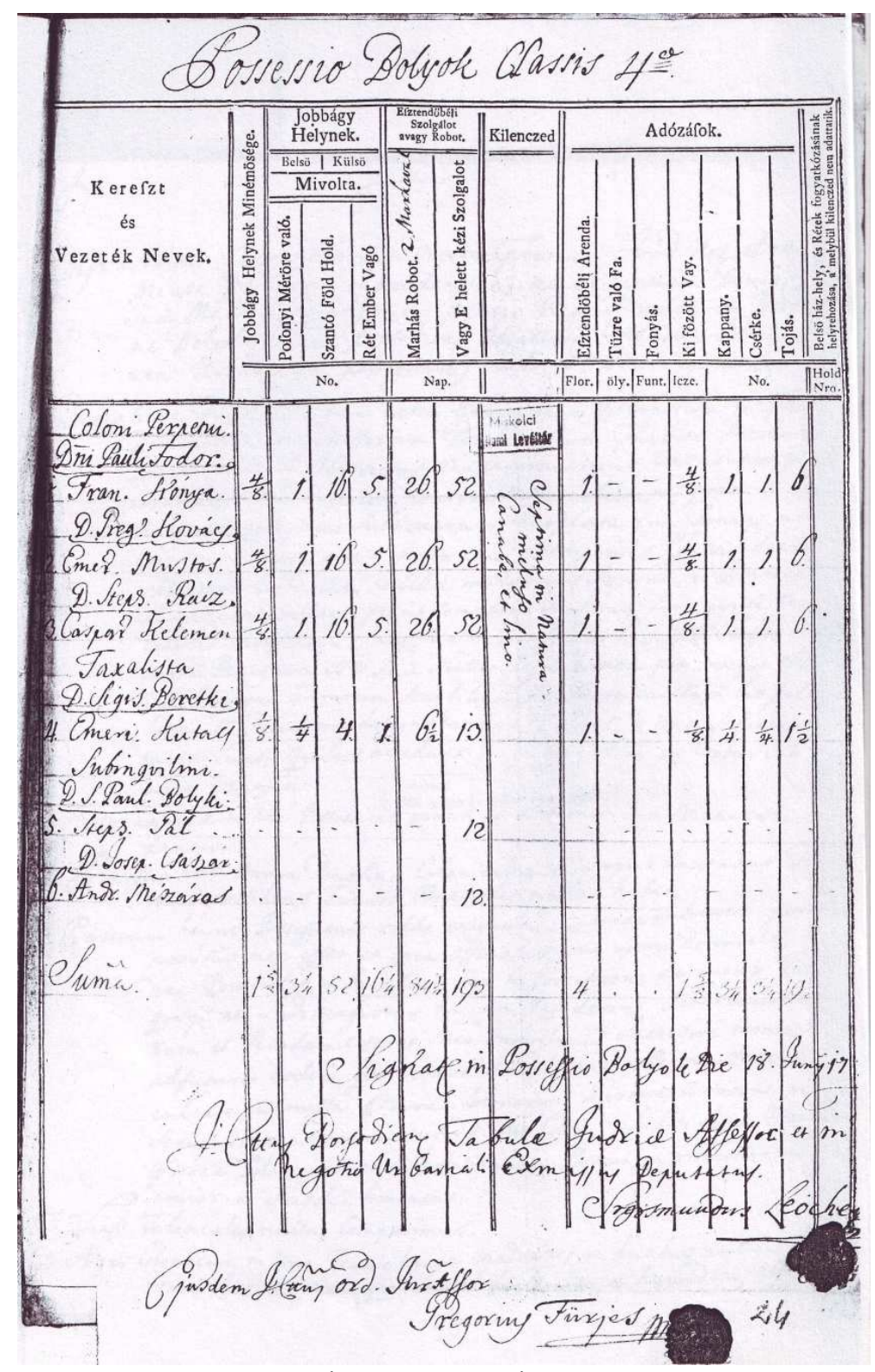

6. kép. Bolyok urbáriuma.

A község urbáriumával zárom a család történetének felvázolását. A Sajóvárkonyi Plébánia anyakönyvei egészen a 20. század közepéig szolgáltatnak adatokat a família genealógiájához. Ezzel egy közel 500 éves időintervallum hidalható át az 1548-as első említés és napjaink között. 


\section{Függelék}

1.

„Mi nemes Gömör vármegyében Felső-Válban lakozó Bolykij Gergely, és feleségem Ivánkaij Susanna aszony, fiainkal mostan élőkkel, úgy mint Bolykij Pállal, és Bolykij Győrgyel, és leányinkal, úgy mint Bolykij Annával, Bolykij Borbálával, és Bolykij Katával, és Bolykij Eőrsébettel, s mind penig ennekutána leendőkkel. Elsőbben-is fel válalván minden testvér atyánk fiainak terheket, valakiket ez ide alább meg irtt dolog concernálhatna, ${ }^{69}$ és adgyuk tudtára mindeneknek, az kiknek illik, ez mi levelünknek rendiben; hogy mi meg tekintvén nemes Borsod vármegyében, Bolyok nevü faluban lakozó Kutacs Imrének, Kutacs Demeternek, Kutacs Albertnek, és azoknak fiaiknak, Kutacs Dijenesnek jámbor, és hivséges jobbágyinknak jámbor, és hivséges szolgálattyokat, és adtúnk, és engedtünk örök szabadságot fiúrúl fiúra mind magoknak, és mind mostan élő, és ennek utána leendő mind á két ágon lévő maradékjoknak irrevocabiliter, ${ }^{70}$ és irremissibiliter, ${ }^{71}$ hét száz magyari forintokban, id est ${ }^{72}$ fl[orenos] 700, egy gyermek lóban, és egy karmazsin csizmában, melly specificaltt sum[m]át statim, ${ }^{73}$ et de facto bonis, ${ }^{74}$ et usualibus monetis, ${ }^{75}$ minékünk le is tettenek, és minket plenarie contentáltanak. ${ }^{76}$ Adtúnk penigh szabadságot ezen felül specificaltt ${ }^{77}$ jámbor jobbágyinknak illyen okon: hogy á data $\mathrm{p}[\mathrm{rae}]$ sentium, $^{78}$ mind magúnk, s mind peniglen maradékúnk eőket semmi jobbágyságnak terhével, szolgálattal, és adózással, dés[z]ma adással eőket nem terhellyük sem magúnk, sem peniglen maradékúnk, sem magokat, sem peniglen maradékjokat, hanem mi tülünk $\mathrm{im}[\mathrm{m}]$ unisek, ${ }^{79}$ és szabadosok légyenek, ugyan azon ház-hellyel, á mellyen mostan laknak, és ennek mindennémü rétével, és főldével, és erdeivel, berkeivel, pástyával, halászó vizével, főld, és réth órtvány őrökségivel edgyüt, malmával, és malom helyével, egy szóval minden a[hhoz] tartozó igaz pertinenciaival, ${ }^{80}$ és jövedelmivel edgyüt, az melly specificaltt ház-helyet is adtúnk eörökben nékik, és ez aránt rajtok lévő minden igaz főldủ úri authoritásunkat, ${ }^{81}$ és szabadcságunkat ellenek plenarie le tészük, úgy hogy ha kedvek, és értékek tészen reá, az mi kegyelmes koronás király urúnktúl eő fölségétűl magoknak szabadon armalist impetrálhassanak, ${ }^{82}$ és

\footnotetext{
${ }^{69}$ Illetne.

${ }^{70}$ Megmásíthatatlanul.

${ }^{71}$ Könyörtelenül.

${ }^{72}$ Vagyis.

${ }^{73}$ A megjelölt összeget nyomban.

${ }^{74}$ És ténylegesen a javakat.

${ }^{75}$ És a szokásos összeget.

${ }^{76}$ Teljesen kielégítettek.

${ }^{77}$ Megjelölt.

${ }^{78}$ Ettől kezdve.

${ }^{79}$ Mentesek.

${ }^{80}$ Tartozékaival.

${ }^{81}$ Tekintélyünket.

${ }^{82}$ Kérhessenek.
} 
hozathassanak, és ez felül specificaltt ház-helyre is regnis consensust ${ }^{83}$ hozathassanak, és azokat meg hozatván, az nemes vármegyén szabadon publicaltathassanak $^{84}$ minden akadály, és meg bántódás nélkül, seőt arra is obligállyuk $^{85}$ magúnkat, hogy az nemes egri káptalanban bé viszszük, és ott-is ezen

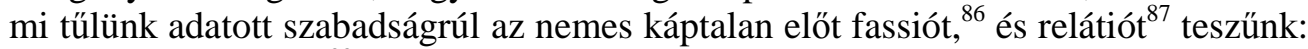
az leg[iti]ma evictiót ${ }^{88}$ magúnkra, és mind az két ágon való, vagy lévő maradékinkra és posteritasinkra ${ }^{89}$ fel vészúk, és fel válallyuk, hogy eőket az felül specificaltt szabadságban meg tartyuk mind magokat, mind peniglen maradékjokat, és posteritássokat. Seőt minden leg[iti]mus impetitorok ${ }^{90}$ ellen meg oltalmazzuk mind magúnk, s-mind maradékúnk magúnk kölcségével, és fáratságával, mind mogokat, s mind penig maradékjokat; hogy ha peniglen casu quo ${ }^{91}$ meg nem oltalmazhatnánk, ávagy oltalmazni nem akarnánk, adúnk arra szabadságot, es auctoritást, ${ }^{92}$ hogy valamelly vármegyében az magyar korona alat jószágúnk találtatik, azon vármegyének szolga-bíráját, az kinek processussában ${ }^{93}$ jószágúnk találtatik, esküttyével edgyüt, sine exmissionalibus, ${ }^{94}$ csak magok házoktúl is ki hihassák, és magoknak az felyül specificaltt capitalis summáigh irremissibiliter satis facialtathassanak, ${ }^{95}$ és executialtathassanak, ${ }^{96}$ nem használván magúnk oltalmára semmi törvényes remediumokkal, ${ }^{97}$ úgy mint had, szüret, aratás, diaeta, ${ }^{98}$ octava, ${ }^{99}$ repulsiókkal, ${ }^{100}$ inhibitiókkal, ${ }^{101}$ hanem szabadosan minden meg bántódás nélkül az executiót $^{102}$ végben vitethessék. Mellynek nagyobb bizonságára, és álandobb voltára adtuk ezen pecsétes levelünket kezünk irásával meg erösitvén, és ide alább coramozó $^{103}$ becsületes személlyek előt. Datum in pos[s]es[s]ione Felső Vál die $2^{\mathrm{a}}$ aprilis anno 1669. ${ }^{104}$ Bolykij Gergely keze kereszt x vonása (ls) Ivánkaij Susanna keze x vonása Bolykij Pál keze x vonása, Bolykij Borbála keze x vonása (ls) Bolykij

\footnotetext{
${ }^{83}$ Királyi jóváhagyást.

${ }^{84}$ Kihirdetethessék.

${ }^{85}$ Kötelezzük.

${ }^{86}$ Bevallást.

${ }^{87}$ Jelentést.

${ }^{88}$ Törvényes szavatosságot.

${ }^{89}$ Utódainkra.

${ }^{90}$ Törvényes vádló.

${ }^{91}$ Abban az esetben.

${ }^{92}$ Tekintélyt.

${ }^{93}$ Járásában.

${ }^{94}$ Törvényes eljárás nélkül.

${ }^{95}$ Főbenjáró összegig könyörtelenül eleget tétethessenek.

${ }^{96}$ Folytathassanak.

${ }^{97}$ Orvosságokkal.

${ }^{98}$ Országgyülés.

${ }^{99} \mathrm{Az}$ ünnep nyolcadik napja, törvényszolgáltatásra való idő.

${ }^{100}$ Visszautasításokkal.

${ }^{101}$ Eltiltásokkal.

${ }^{102}$ Végrehajtást.

${ }^{103}$ Hitelesítő.

${ }^{104}$ Kelt Felsővály faluban, 1669. április 2-án.
} 
Panna keze x vonása (ls), Bolykij Kata keze x vonása (ls). Coram me ${ }^{105}$ Georgio Losonczij judice nobilium co[mi]t[a]tus Gömöriensis ${ }^{106} \mathrm{mp}$. (ls) Coram me Stephano Literati ${ }^{107}$ (ls) mp. Deme Bálint keze x vonása (ls) Coram me Thoma Bolykij (1s) Székely Márton keze x vonása (ls) Coram me Stephano Lapos (ls) Német János keze x vonása."

Nos Leopoldus, Dei gratia electus Romanorum imperator, semper augustus, ac Germaniae, Hungariae, Bohemiae, Dalmatiae, Croatiae, Sclavoniae, Ramae, Serviae, Gallitiae, Lodomeriae, Cumaniae, Bulgariaeque etc. rex, archidux Austriae, dux Burgundiae, Brabantiae, Styriae, Carinthiae, Carnioliae, Marchio Moraviae, dux Lucemburgae, ac superioris et inferioris Silesiae, Wierthembergae, et Thekae, princeps Sveviae, comes Habspurgi, Tyrolis, Ferreti, Kyburgi et Goritiae, landtgravius Alsatiae, marchio Sacri Romani Imperii supra Anasum, Burgoviae, ac superioris et inferioris Lusatiae, dominus Marchiae Sclavonicae, Portus Naonis et Salinarum, etc.

Memoriae commendamus tenore praesentium significantes, quibus expedit, universis, quod nos cum ad nonnullorum fidelium nostrorum humillimam supplicationem nostrae propterea factam maiestati, tum vero attentis et consideratis fidelitate et fidelibus servitiis fidelis nostri Emerici Kutats, quae ipse sacrea primum regni nostri Hungariae coronae et deinde maiestati nostrae pro locorum et temporum varietate fideliter exhibuit et impendit ac sese imposterum quoque exhibere et impendere velle pollicetur. Cum igitur ob id, tum vero ex gratia et munificentia
Mi Lipót, Isten kegyelméböl a rómaiak felséges császára, és Németország, Magyarország, Csehország, Dalmácia, Horvátország, Szlavónia, Ráma, Szerbia, Galícia, Lodoméria, Kunország és Bulgária, stb. királya, Ausztria főhercege, Burgundia, Brabant, Stíria, Karintia, Krajna, Morvaország őrgrófja, Luxemburg, Felsö-, és Alsó-Szilézia, Württemberg és Téka hercege, Szvévia fejedelme, Habsburg, Tirol, Ferrete, Kiburg és Görz grófja, Elzász örgrófja, az Enns felett fekvö Szent Római Birodalom, Bajorország, továbbá Felsö-, és AlsóLuzsácia örgrófja, a Vend Örgrófság, Pordenone és Salzburg ura, stb.

Emlékezetül adjuk jelen oklevelünk erejével, tudatván mindazokkal, akiket illet, hogy Mi, néhány hívünknek Felségünk elé terjesztett legalázatosabb kérelmére, továbbá pedig meggondolván és figyelembe vévén hívünknek Kutats Imrének hüségét és hüséges szolgálatait, melyeket Ö először Magyar Királyságunk Szent Koronájának, azután Felségünknek különböző helyen és időben híven teljesített és a jövőben is tenni és teljesíteni ígérkezik; egyrészt ezért, azoknak, akik Nekünk és a

\footnotetext{
${ }^{105}$ Elöttem.

${ }^{106}$ Gömör vármegye szolgabírája.

${ }^{107}$ Deák.
} 
nostra regia, qua quosque de nobis et republica Christiana benemeritos, virtutisque colendae studiosos antecessorum nostrorum divorum quondam Hungariae regum exemplo prosequi eisque certa virtutum suarum monimenta, quae ad maiora quaeque praestanda eos incitare possent, decernere consueverunt. Eundem itaque Emericum Kutats, ac per eum Margaretham Balaspali consortem, et Dionysium filium, ac Ursulam filiam, nec non Demetrium et Albertum similiter Kutats, fratres suos carnales et uterinos, prout etiam uxores eorundem Catharinam Szalmasy, ac Dorotheam Vass, una cum filio itidem Alberto, filiabusque Anna, Elisabetha, Sophia, Catharina et Dorothea, pariformiter Kuthats, de regiae nostrae potestatis plenitudine et gratia speciali in coetum et numerum verorum atque indubitatorum regni nostri Hungariae et Partium ei subiectarum nobilium duximus cooptandum, annumerandos et adscribendos. Annuentes et ex certa nostra scientia animoque deliberato concedentes ut ipsi a modo imposterum futuris et perpetuis semper temporibus omnibus illis gratiis, honoribus, indultis, privilegiis, libertatibus, praerogativis et immunitatibus, quibus caeteri veri antiqui et indubitati iamfati regni nostri Hungariae et Partium ei subiectarum nobiles hactenus quomodolibet de iure vel consuetudine usi sunt et gavisi, utunturque et gaudent, uti, frui et gaudere possint ac valeant; haeredesque et posteritates ipsorum utriusque sexus universae valeant atque possint.

In cuius quidem nostrae erga ipsos exhibitae gratiae et clementiae ac liberalitatis testimonium veraeque et indubitatae nobilitatis signum haec arma seu nobilitatis insignia. Scutum videlicet militare rubri coloris trigoni instar erectum, cuius fundum occupat viridis triiugis kereszténységnek érdemeket és tiszteletet szereztek, királyi kegyelmünk és bőkezűségünk folytán elődeinknek, Magyarország néhai dicső királyainak példáját követvén, erényeiknek jutalmát - mely őket még nagyobbak teljesítésére buzdíthatja - meg szoktuk adni.

Ezért tehát ugyanezt a Kutats Imrét, általa feleségét Balázspály Margitot, fiát Dénest és lányát Orsolyát, továbbá Demetert és Albertet, akik hasonlóképp Kutatsok, az ö saját, és anyai részről való rokonaikat, miként feleségeiket is, Szalmásy Katalint és Vass Dorottyát, hasonlóképp fiát, Albertot és lányait: Annát, Erzsébetet, Zsófiát, Katalint és Dorottyát, akik ugyancsak Kuthatsok, királyi hatalmunk teljességével és különös kegyelmünkkel kivévén elhatároztuk, hogy Magyarországnak és kapcsolt részeinek igazi és kétségtelen nemeseinek rendjébe felvesszük, befogadjuk és soroljuk.

Megengedvén és megfontolt elhatározásból beleegyezvén, hogy ők mostantól fogva a jövőben örök időkig mindazon kegyekkel, tisztségekkel, kedvezményekkel, kiváltságokkal, szabadságokkal, előjogokkal és mentességekkel, amelyekkel Magyarországunk és a kapcsolt részek többi igazi, régi és kétségtelen nemesei eddig bármilyen jog vagy szokás alapján éltek és élnek, azokkal mindkét nembeli összes örököseik és utódaik élhessenek, azokat élvezhessék és bírhassák.

Irántuk tanúsított kegyelmünk, jóakaratunk és nagylelküségünk bizonyságául, továbbá igazi és kétségtelen nemességük jeléül ezt a nemesi címert, avagy jelvényt adományozzuk. Látható egy egyenesen álló, háromszög alakú, vörös színű katonai pajzs, ennek alját 
monticulus in eiusque depressioribus partibus integer fulvus leo naturaliter effigiatus, divaricatis posterioribus pedibus, corporis mole arrecta erecte stare, ore patulo ac lingua rubicunda exerta caudaque bifurcata ad dorsum elevata, anteriorum vero pedum sinistro virentem palmam, dextro autem evaginatam frameam tenere, atque in dextram scuti partem conversus esse visitur, in superioribus porro scuti angulis, singulis candidis liliis prominentibus. Scuto incumbentem galeam militarem craticulatam sive apertam regio diademate, exeoque alium leonem inferiori per omnia similem inguinetenus eminem, proferente ornatam. A summitate vero sive cono galeae laciniis, seu lemniscis hinc flavis et caeruleis, illinc autem candidis et rubris, in scuti extremitates sese diffundentibus scutumque ipsum decenter exornantibus, quemadmodum haec omnia in principio se capite praesentium literarum nostrarum pictoris manu et artificio propriis suis coloribus depicta esse conspiciuntur. Eidem Emerico Kutats, ac per ipsum superius nominatim specificatis personis ipsarumque haeredibus et posteritatibus utriusque sexus universis gratiose danda duximus et conferenda. Decernentes et ex certa nostra scientia animoque deliberato concedentes ut ipsi a modo imposterum futuris et perpetuis semper temporibus eadem arma seu nobilitatis insignia more aliorum verorum atque indubitatorum memorati regni nostri Hungariae et Partium ei subiectarum nobilium sub iisdem iuribus praerogativis, indultis, libertatibus et immunitatibus, quibus ipsi vel natura vel antiqua consuetudine usi sunt et gavisi utunturque et gaudent ubique in praeliis, certaminibus, pugnis, hastiludiis, torneamentis, duellis, monomachiis aliisque omnibus et singulis ac quibusvis exercitiis militaribus et nobilitaribus, nec non egy háromhalmú zöld hegyecske foglalja el, aminek a lentebbi részén egy teljes, vörhenyes oroszlán, természetes módon lefestve, hátsó lábait szétterpesztve, teljes testével felegyenesedve egyenesen áll; szája nyitva, vöröslő nyelve kinyújtva, és kétágú farka háta fölé emelve, az elülső bal mancsában zöldellő pálmaágat, jobbjában pedig kivont szablyát tartva, a pajzs jobb oldala felé fordulva látható. A pajzs felső sarkaiban egy-egy fehér liliom mutatkozik. A pajzsra rostélyos vagy nyitott katonai sisak támaszkodik királyi koronával, ebből másik oroszlán, az alsóval teljesen egyező, derékig kiemelkedve illően díszíti azt.

A sisak ormáról vagy tetejéröl innen aranysárga és kék, onnan pedig fehér és vörös szalagok vagy foszlányok a pajzs széleire ráomlanak, miként mindez jelen oklevelünk elején, a festő keze által müvészien, saját színeivel megfestve is látható.

Ennek a Kutats Imrének és ő általa a fent név szerint felsorolt személyeknek és mindkét nembeli örököseiknek és utódaiknak ezt a címert kegyesen adtuk és ajándékoztuk. Elhatározván eltökélt szándékkal és megfontolt lélekkel megengedvén, hogy ők ettől fogva örökidőkig mindig ezt a címert, avagy nemesi jelvényt Magyarország és az alávetett részek igazi, és kétségtelen nemeseinek a szokása szerint ugyanazokkal a jogokkal, elöjogokkal, kedvezményekkel, szabadságokkal és kiváltságokkal, amelyekkel azok akár természetnél, akár régi szokásnál fogva éltek és amelyeknek örvendtek, élnek és örvendenek mindenütt: csatákban, ütközetekben, dárdavetéseken, lovagi tornákon, bajvívásokon, párviadalokon, egyéb katonai és nemesi gyakorlatokon, nemkülönben pecséteken, kárpitokon, 
sigillis, velis, cortinis, aulaeis, annulis, vexillis, clypeis, tentoriis, domibus et sepulchris generaliter vero in quarumlibet rerum et expeditionum generibus sub merae vetustae ac syncerae nobilitatis titulo, quo eos, ab omnibus cuiuscunque status, dignitatis, conditionis et praeeminentiae homines existant, insignitos et ornatos dici, nominari, haberi et reputari volumus et mandamus, ferre, gestare, illisque in aevum uti, frui et gaudere possint ac valeant; haeredesque et posteritates ipsorum utriusque sexus universae valeant atque possint. Imo nobilitamus, damus et conferimus praesentium per vigorem.

In cuius rei memoriam firmitatemque perpetuam praesentes literas nostras secreto sigillo nostro, quo ut rex Hungariae utimur, impendenti communitas. Eidem Emerico Kutats, ac per eum supra denotatis personis ipsarumque haeredibus et posteritatibus utriusque sexus universis gratiose dandas duximus et concedendas. Datum per manus fidelis nostri nobis dilecti, reverendi Francisci Szegedy episcopi Vacziensis consiliarii nostri et aulae nostrae per dictum Regnum nostrum Hungariae Cancellarii in civitate nostra Vienna Austriae, die vigesima nona mensis octobris anno domini Millesimo Sexcentesimo Sexagesimo Nono, regnorum nostrorum Romani duodecimo, Hungariae et reliquorum decimo quinto, Bohemiae vero anno decimo quarto. Reverendissimis ac venerabilibus in Christo patribus, dominis Georgio Szelepcheny metropolitanae Strigoniensis et altero Georgio Szecheny Colocensis et Bachiensis ecclesiarum canonice unitarum archiepiscopis, Thoma Palffy ab Erdeod Agriensis, fratre Martino Borkovich electo Zagrabiensis, Georgio Barsony electo Varadiensis, Matthaeo Szenththamassy electo Transylvaniensis, Leopoldo a üstökön, szőnyegeken, gyürükön, zászlókon, pajzsokon, hajítófegyvereken, otthonaikban, sírhalmokon, és általában bárminemü tárgyon és bármiféle vállalkozás során a régi és hamisítatlan nemesség címén, amellyel őket és valamennyi mindkét nembeli örökösüket bármely rangú, rendü, állapotú és méltóságú férfiú részéröl felékesítettnek és felruházottnak mondatni, neveztetni, elismertetni és tartatni akarjuk és a címert hordani és viselni megparancsoljuk, valamint, hogy azt örökké használhassák, élvezhessék és annak örvendhessenek. Söt, őket jelen oklevelünk által megnemesítjük és nekik nemességet adunk és adományozunk.

Ennek az emlékére és örök erősségére titkos függőpecsétünkkel - melyet, mint Magyarország királya használunk megerősített nemesi kiváltságlevelünket ugyanennek a Kutats Imrének, örököseinek és mindkét nembeli utódainak kiadni és jóváhagyni rendeltük.

Kiadatott a Mi öszintén kedvelt hívünk, főtisztelendő Szegedy Ferenc váci püspök, tanácsosunk és magyarországi kancellárunk által az ausztriai Bécs városunkban, az Úr 1669. évének október havának 29. napján, római [birodalombeli] uralkodásunk 12., a magyarországinak 15., a csehországinak pedig a 14. évében.

Amikor a fötisztelendő és tisztelendő atyák a Krisztusban Szelepcsényi György esztergomi érsek, másrészt Széchenyi György a kánonilag egyesült kalocsai és bácsi egyházak érseke, erdődi Pálffy Tamás egri, Borkovich Márton szerzetes testvér zágrábi, Bársony György választott váradi, Szenttamássy Mátyás választott erdélyi, Kolonich Lipót választott nyitrai, és a 
Kolonich electo Nitriensis, iamfato Georgio Szecheny Administratore Iauriensis, Stephano Sennyey de Kys Sennye Wesprimiensis, eodem Francisco Szegedy Vacziensis, Hyacinto Macripodary electo Chanadiensis, Ioanne Gubasoczy electo Quinqueecclesiensis, Ioanne Szaszy electo Sirmiensis, Francisco Gorup electo Noviensis, fratre Christophoro de Roxas electo Tininiensis, Ioanne Szmolianovich electo Segniensis et Modrusiensis, episcopatu Bosnensis vacante et Georgio Berdoczy electo Rosonensis ecclesiarum episcopis ecclesias dei feliciter gubernantibus.

Item spectabilibus ac magnificis, officio Palatinali dicti regni nostri Hungariae vacante, comite Francisco de Nadasd iudice curiae nostrae Regiae, comite Petro a Zrinio attactorum regnorum nostrorum Dalmatiae, Croatiae et Sclavoniae bano, comite Adamo Forgach de Ghymes tavernicorum, comite aeque Adamo de iamfata Zrin agazonum, comite Nicolao Palffy de antedicta Erdeod cubiculariorum, comite itidem Nicolao Draskovich de Trakostyan ianitorum, comite Georgio Illyeshazy de eadem dapiferorum, comite Christophoro de Battyan pincernarum, comite Paulo Eszterhassy de Galantha curiae nostrorum regalium in Hungaria magistris ac memorato comite Nicolao Palffy de praelibata Erdeod, comite Posoniensis caeterisque quam plurimis praecitati regni nostri Hungariae comitatus tenentibus et honores.

Leopoldus m.p. Franciscus Szegedy m.p. Episcopus Vacziensis

Anno Domini millesimo sexcentesimo septuagesimo die decima nona mensis Martii. In generali congregatione comitatus Borsodiensis in oppido Miskolcz celebrata. Praesentes sacrae caesarae regiaeque maiestatis litterae armales nobilitationis már mondott Széchenyi György győri adminisztrátor, kis sennyei Sennyey István veszprémi, Szegedy Ferenc váci, Macripodáry Jácint választott csanádi, Gubasóczy János választott pécsi, Szászy János választott szerémi, Gorup Ferenc választott novi, Roxas Kristóf barát választott tinnini, Szmolianovich János választott zenggi és modruszi, miközben a boszniai püspökség üresedésben lévén, Berdóczy György választott rosznói püspökök Isten egyházát szerencsésen kormányozzák.

Továbbá, tekintetes és nagyságos a már előbb mondott Magyar Királyságunknak nádori hivatala betöltetlen lévén, gróf Nádasdy Ferenc országbíró, gróf Zrínyi Péter Dalmácia, Horvátország és Szlavónia bánja, gróf gimesi Forgách Ádám tárnokmester, továbbá a már említett Zrínyi Ádám fölovászmester, erdődi gróf Pálffy Miklós főkamarás, trakostyáni gróf Draskovich Miklós főajtónálló, gróf Illésházy György fóétekfogó, gróf Batthyány Kristóf föpohárnok, galántai gróf Esterházy Pál a magyar királyi udvarunkban föudvarmester, a már említett erdődi gróf Pálffy Miklós pozsonyi ispán, valamint a többiek Magyarország vármegyéit igazgatván.

Lipót s.k.

s.k.

Szegedy Ferenc váci püspök

Az Úr 1670. évében március hó 19. napján.

Borsod vármegyének Miskolc mezővárosában megtartott általános közgyülésében. A jelenlévő szent császári és királyi fenség címeres nemesítő 
privilegialis generoso ac egregio domino Stephano Szentpéteri de eadem vice comitis, Andrea Deöry altero Andrea Bököny jurate Pap et Martino Bér judicatus nobilium istius comitatus Borsodiensis officiis pro tempore fungentibus exhibitae et praesentatae ac postae cum indubitata suprascriptarum personarum in album ac numerum istius comitatus nostri nobilium facta receptione nemine prorsus contradictione vel reclamante publicatae proclamatae solenniter ac etiam eisdem personis extradatae sunt per me juratum dicti comitatus ejusdem Borsodiensis notarius Matthiam Aszalay. levelét nemzetes és vitézlő Szentpéteri István úr, ugyanannak alispánja, Dőry András és Bököny András esküdt, Pap és Bér Márton szolgabírák, Borsod vármegye hivatalainak jelenlegi viselői által kihirdetésre és bemutatásra került, majd a fent írt személyek kétségtelenül beírattak a vármegye nemeseinek jegyzékébe és sorába, ellentmondás vagy tiltakozás nélkül, ünnepélyesen közzétételre és kikiáltásra került, majd ugyanezeknek a személyeknek kiadatott általam, a mondott Borsod vármegyének jegyzője Aszalay Mátyás által. 